\title{
Ultrafine particles in four European urban environments: \\ Results from a new continuous long-term monitoring network
}

J. Hofman (VMM)

J. Staelens (VMM)

R. Cordell (University of Leicester)

c. Stroobants (VMM)

N. Zikova (Charles University, Prague)

S.M.L. Hama (University of Leicester / University of Sulaimani, Kurdistan Region, Sulaimani, Iraq) $888: 888888888: 888888$ K.P. Wyche (University of Brighton) G.P.A. Kos (ECN)

S. van der Zee (GGD Amsterdam)

K.L. Smallbone (University of Brighton)

E.P. Weijers (ECN)

P.S. Monks (University of Leicester)

E. Roekens (VMM)

\section{April 2016}

ECN-W--16-017 


\title{
Ultrafine particles in four European urban environments: Results from a new continuous long-term monitoring network
}

\author{
E. Roekens ${ }^{a}$ \\ a Flanders Environment Agency (VMM), Department Air, Environment and Communication, Belgium \\ ${ }^{\mathrm{b}}$ University of Leicester, Department of Chemistry, UK \\ c Institute for Environmental Studies, Faculty of Science, Charles University, Prague, Czech Republic \\ ${ }^{\mathrm{d}}$ Department of Chemistry, School of Science, University of Sulaimani, Kurdistan Region, Sulaimani, Iraq \\ ${ }^{\mathrm{e}}$ Air Environment Research, University of Brighton, School of Environment and Technology, UK \\ ${ }^{\mathrm{f}}$ Energy Research Centre of the Netherlands (ECN), Environment \& Energy Engineering, The Netherlands \\ ${ }^{g}$ Public Health Service of Amsterdam, Department of Air Quality, The Netherlands
}

J. Hofman a, *, J. Staelens a , R. Cordell ${ }^{\text {b }}$, C. Stroobants a , N. Zikova ${ }^{\text {c }, ~ S . M . L . ~ H a m a ~}{ }^{\text {b, d }}$, K.P. Wyche ${ }^{\text {e }}$, G.P.A. Kos ${ }^{\text {f }}$, S. Van Der Zee ${ }^{\text {g }}$, K.L. Smallbone ${ }^{\text {e }}$, E.P. Weijers ${ }^{\text {f }}$, P.S. Monks ${ }^{b}$,

\section{H I G H L I G H T S}

- We evaluated spatiotemporal UFP levels in Amsterdam, Antwerp, Leicester and London.

- Size-resolved particle numbers provide valuable information on contributing sources.

- Road traffic seems to be a major UFP contributor in the studied urban environments.

- New particle formation (NPF) events were observed in all cities.

- Consideration is needed when allocating UFP monitoring sites in urban environments.

\section{A R T I C L E I N F O}

\section{Article history:}

Received 28 December 2015

Received in revised form

4 April 2016

Accepted 8 April 2016

\section{Keywords:}

UFP

Urban particle size distribution

Amsterdam

Antwerp

Leicester

London

\begin{abstract}
A B S T R A C T
To gain a better understanding on the spatiotemporal variation of ultrafine particles (UFPs) in urban environments, this study reports on the first results of a long-term UFP monitoring network, set up in Amsterdam (NL), Antwerp (BE), Leicester (UK) and London (UK). Total number concentrations and size distributions were assessed during 1-2 years at four fixed urban background sites, supplemented with mobile trailer measurements for co-location monitoring and additional short-term monitoring sites. Intra- and interurban spatiotemporal UFP variation, associations with commonly-monitored pollutants $\left(\mathrm{PM}, \mathrm{NO}_{\mathrm{x}}\right.$ and $\left.\mathrm{BC}\right)$ and impacts of wind fields were evaluated. Although comparable size distributions were observed between the four cities, source-related differences were demonstrated within specific particle size classes. Total and size-resolved particle number concentrations showed clear traffic-related temporal variation, confirming road traffic as the major UFP contributor in urban environments. New particle formation events were observed in all cities. Correlations with typical traffic-related pollutants $\left(\mathrm{BC}\right.$ and $\mathrm{NO}_{\mathrm{x}}$ ) were obtained for all monitoring stations, except for Amsterdam, which might be attributable to UFP emissions from Schiphol airport. The temporal variation in particle number concentration correlated fairly weakly between the four cities $\left(r_{s}=0.28-0.50\right.$, COD $=0.28-0.37$ ), yet improved significantly inside individual cities $\left(r_{s}=0.59-0.77\right)$. Nevertheless, considerable differences were still obtained in terms of particle numbers ( $20-38 \%$ for total particle numbers and up to $49 \%$ for size-resolved particle numbers), confirming the importance of local source contributions and the need for careful consideration when allocating UFP monitoring stations in heterogeneous urban environments.
\end{abstract}

๑) 2016 Elsevier Ltd. All rights reserved.
* Corresponding author. Research Foundation Flanders (FWO), University of Antwerp, Department of Bioscience Engineering, Groenenborgerlaan 171, 2020, Antwerp, Belgium.

E-mail address: Jelle.Hofman@uantwerp.be (J. Hofman).

\section{Introduction}

Atmospheric aerosols, ranging from several nanometers to 
approximately $100 \mu \mathrm{m}$ in diameter, are composed of primary particles, emitted from both anthropogenic activities and natural sources, and secondary particles formed by gas-to-particle conversion processes including nucleation and condensation (Donaldson et al., 2001; Querol et al., 2011; Viana et al., 2015). They are typically characterized by varying size modes, i.e. $<10 \mathrm{~nm}$ (nucleation), 10-100 nm (Aitkin mode), $100 \mathrm{~nm}-1 \mu \mathrm{m}$ (accumulation mode) and coarse mode ( $>1 \mu \mathrm{m})$, providing information on the contributing emission sources and attributing chemical and physical processes (Vu et al., 2015). Current air quality legislation focusses on monitoring, limiting and reducing mass concentrations of these airborne particles. However, recent toxicological and epidemiological research suggests that particle numbers may constitute better links to health endpoints than mass concentration (Donaldson et al., 2001; Harrison et al., 2000; Kelly and Fussell, 2012). Ultrafine particles (UFPs) in particular, consisting of aerosols smaller than $100 \mathrm{~nm}$, have been demonstrated to cause adverse health effects owing to their ability to penetrate deeply into the respiratory system and enter the bloodstream inducing inflammation and, potentially promoting cardiovascular and respiratory conditions. In ambient air, ultrafine particles are dominant in terms of particle number ( $80-90 \%$ of all particles), but negligible in terms of particle mass, and are, therefore, inadequately quantified in current (mass-based) air quality monitoring networks. This especially holds true in urban areas, where concentrated local emissions sources and a complex urban topography are known to reduce pollutant dispersion. Consequently, there is a clear need for a thorough understanding of the spatiotemporal variation of UFPs.

There have been several short-term studies which have contributed to existing knowledge on the number/size distribution of specific UFP sources, and attributing formation and transformation processes of UFPs (Brines et al., 2015; Dall'Osto et al., 2013; González et al., 2011; Hudda et al., 2014; Keuken et al. 2015; Kozawa et al., 2012; Zhu et al., 2002). Studies reporting on long-term simultaneous UFP measurements at multiple sites are, however, scarce (Pey et al., 2008; Reche et al., 2011; Von BismarckOsten et al., 2013). Nevertheless, such networks are vital to elucidate the complex relationship between local emission sources, meteorological processes, atmospheric transformation and the resulting aerosol number, size and distribution at sites with differing characteristics. This study reports on the first results of a novel North-West European UFP monitoring network, established in Amsterdam, Antwerp, Leicester and London. The work was carried out as part of the Joint Air Quality Initiative (www.joaquin.eu), an INTERREG IVB funded European project, aimed at supporting health-oriented air quality policies in Europe. The main aims were to gain more insight in the spatiotemporal variation in UFP number concentration and size distribution and to assess the added value of UFP data compared to more commonly measured parameters such as particulate matter $\left(\mathrm{PM}_{\mathrm{x}}\right)$ and nitrogen oxides $\left(\mathrm{NO}_{\mathrm{x}}\right)$.

\section{Material and methods}

\subsection{Monitoring sites}

An UFP monitoring network was set up in four NW European cities (Fig. 1), consisting of four fixed monitoring sites at urban background locations in Amsterdam (the Netherlands; AD1), Antwerp (Belgium; AP1), Leicester (United Kingdom; LE1) and London (United Kingdom; LO1). In addition to the fixed monitoring sites, a mobile monitoring unit was deployed for comparative UFP measurements collocated with all fixed monitoring sites $(1 \mathrm{M})$ and for additional UFP measurements at a second urban background site (2 M) in Amsterdam (6.2 km from AD1), Antwerp (1.3 km from AP1) and Leicester (1.2 km from LE1). Hence, UFPs were measured at seven urban background locations across NW Europe (Fig. 1).

The UFP measurements started in April 2013 in Amsterdam and Antwerp, and later in Leicester (November 2013) and London (April 2014) owing to legislation issues. Results up to March 2015, are discussed, hence the discussion covers a period of 1-2 years depending on the site considered. The measurements by the mobile monitoring unit were carried out during 2-4 weeks next to the fixed stations and during 2-7 weeks at the additional urban background sites (AD2M, AP2M, LE2M) (Table 1).

\subsection{Instrumentation}

\subsubsection{Air quality data}

Several commercially available UFP instruments were evaluated via a comprehensive literature review and laboratory test, in order to choose the most appropriate instrumentation and methodology for particle number and size distribution measurements under continuous monitoring network conditions. Based on this evaluation, three instruments were selected for application in the UFP monitoring network (Table 2).

Total UFP number concentrations (TNC; \# $\mathrm{cm}^{-3}$ ) were obtained by means of a water-based Environmental Particle Counter (EPC) at each monitoring station. After initial tests, the high-flow inlet mode (3 $1 \mathrm{~min}^{-1}$ ) was applied to minimize particle losses. Size-resolved particle number concentrations (PNC; \# $\mathrm{cm}^{-3}$ ) were obtained using two different instruments (UFPM and SMPS) owing to legislation issues with the radioactive source $\left({ }^{85} \mathrm{Kr}\right)$ at the UK sites. In Amsterdam (AD1) and Antwerp (AP1), particle number concentrations in 45 different size classes were obtained by a scanning mobility particle sizer (SMPS). In Leicester (LE1) and London (LO1), UFPs were quantified in six size classes $(20-30,30-50,50-70$, $70-100,100-200$ and $>200 \mathrm{~nm}$ ), using an UFPM (Table 2). In brief, the operating principle of the SMPS comprises radioactive $\left({ }^{85} \mathrm{Kr}\right)$ charging of particles, followed by size segregation based on particle electrical mobility using a differential mobility analyser (L-DMA) and particle counting by means of a butanol-based condensation particle counter (CPC). The UFPM principle of operation is based on electrical diffusion charging of the particles, size segregation by means of a DMA, followed by aerosol detection using a Faraday cup electrometer

A Multi-Angle Absorption Photometer (MAAP 5021, Thermo Scientific) was installed in all monitoring stations to determine ambient black carbon $(\mathrm{BC})$ concentrations $\left(\mu \mathrm{g} \mathrm{m}^{-3}\right)$, using the default specific attenuation factor (sigma) of $6.6 \mathrm{~m}^{2} \mathrm{~g}^{-1}$, based on Petzold et al. (2002). In addition to the UFP and BC instruments in the fixed monitoring stations, continuous air quality monitors were already available for $\mathrm{NO}_{\mathrm{x}}$ (Thermo 42i in AP1, LE1 and LO1 and a API 200A in AD1), $\mathrm{PM}_{10}$ (BAM1020 in AD1, ESM FH62 I-R and FIDAS 200 in AP1 and TEOM-FDMS in LO1) and PM 2.5 (BAM1020 in AD1, ESM FH62 I-R and FIDAS 200 in AP1 and TEOM-FDMS in LE1 and LO1). The mobile monitoring unit was equipped with all UFP instrumentation (EPC, UFPM, SMPS) and a MAAP 5012 for atmospheric BC measurements. For the EPC and UFPM instruments an Environmental Sampling System (ESS; TSI 3031200) was used with a $\mathrm{PM}_{10}$ inlet, sharp-cut $\mathrm{PM}_{1}$ cyclone and Nafion dryer. The EPC in AD1 and AP1 were individually connected to an ESS. In LE1, LO1 and the trailer, two instruments (EPC and UFPM) were connected to one ESS. The SMPS devices had an individual Grimm sampling system with TSP inlet and Nafion dryer. Standard operating procedures were created for the applied instrumentation to ensure that comparable monitoring data was collected at the seven locations (monitoring artefacts, e.g. inlet systems, maintenance frequency etc.).

Before the instruments were installed at the monitoring sites, they were intercompared in an initial co-location monitoring 


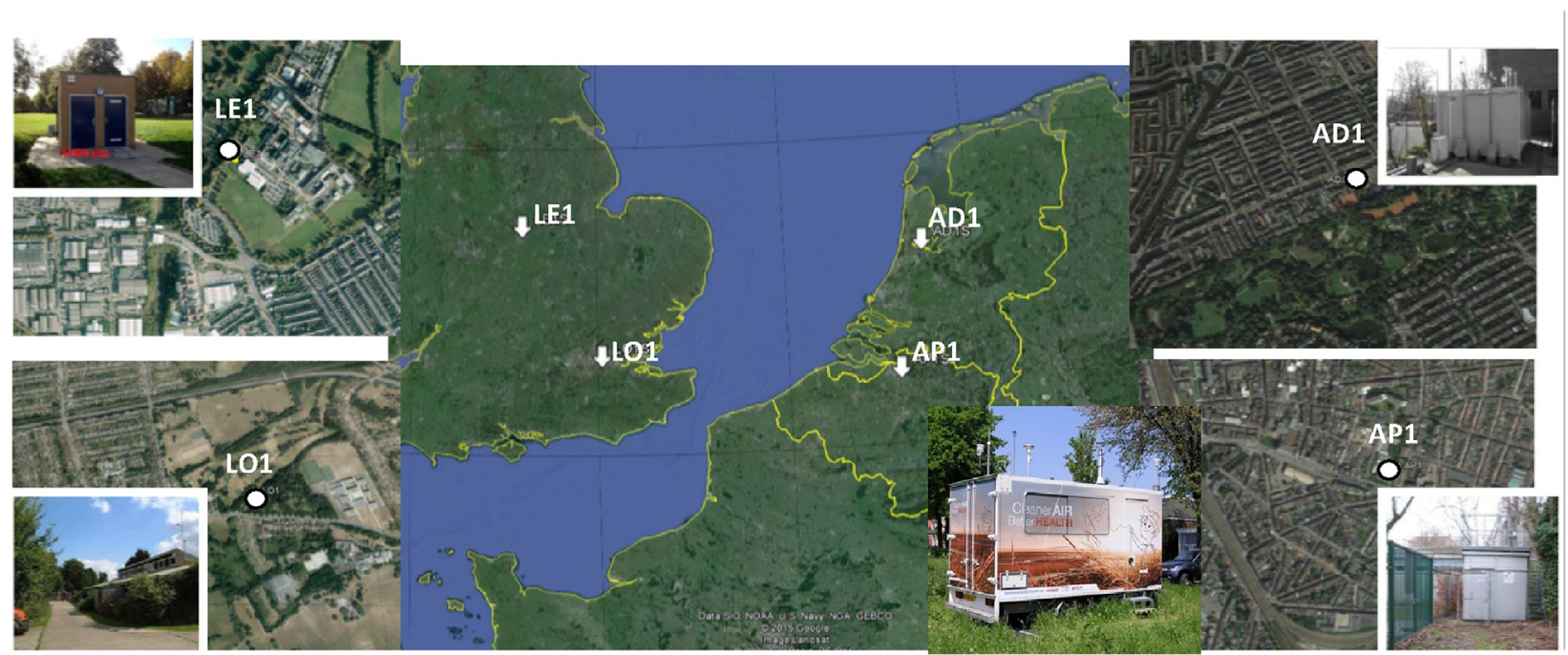

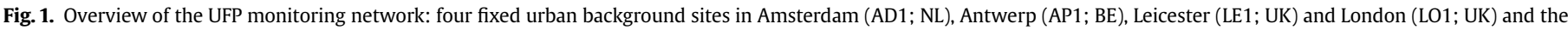
mobile monitoring unit for additional UFP measurements at a second urban background site in three cities (AD2M, AP2M and LE2M).

Table 1

Overview of the applied fixed and mobile unit monitoring sites of the UFP monitoring network.

\begin{tabular}{|c|c|c|c|c|c|c|c|c|c|}
\hline \multirow[t]{2}{*}{ City } & \multirow[t]{2}{*}{ Code } & \multirow[t]{2}{*}{ Fixed/Mobile } & \multirow[t]{2}{*}{ Name } & \multirow{2}{*}{$\begin{array}{l}\text { Distance to main } \\
\text { street }(\mathrm{m})\end{array}$} & \multirow{2}{*}{$\begin{array}{l}\text { Traffic intensity } \\
\text { (veh/day) }\end{array}$} & \multicolumn{2}{|l|}{ Coordinates } & \multicolumn{2}{|c|}{ Monitoring period } \\
\hline & & & & & & Latitude & Longitude & Start & End \\
\hline \multirow[t]{3}{*}{ Amsterdam } & AD1 & Fixed & Vondelpark & 64 & 15000 & $52^{\circ} 21^{\prime} 35^{\prime \prime} \mathrm{N}$ & $4^{\circ} 51^{\prime} 59^{\prime \prime} \mathrm{E}$ & $01 / 04 / 2013$ & $31 / 03 / 2015$ \\
\hline & AD1M & Mobile & Vondelpark & 64 & 15000 & $52^{\circ} 21^{\prime} 35^{\prime \prime} \mathrm{N}$ & $4^{\circ} 51^{\prime} 59^{\prime \prime} \mathrm{E}$ & $17 / 04 / 2013$ & $14 / 05 / 2013$ \\
\hline & AD2M & Mobile & Nieuwendammerdijk & 20 & $<500$ & $52^{\circ} 23^{\prime} 21^{\prime \prime} \mathrm{N}$ & $4^{\circ} 56^{\prime} 38^{\prime \prime} \mathrm{E}$ & $14 / 05 / 2013$ & $30 / 05 / 2013$ \\
\hline \multirow[t]{3}{*}{ Antwerp } & AP1 & Fixed & Borgerhout & 30 & 29500 & $51^{\circ} 12^{\prime} 35^{\prime \prime} \mathrm{N}$ & $4^{\circ} 25^{\prime} 55^{\prime \prime} \mathrm{E}$ & $01 / 04 / 2013$ & $31 / 03 / 2015$ \\
\hline & AP1M & Mobile & Borgerhout & 30 & 29500 & $51^{\circ} 12^{\prime} 35^{\prime \prime} \mathrm{N}$ & $4^{\circ} 25^{\prime} 55^{\prime \prime} \mathrm{E}$ & $04 / 11 / 2013$ & $19 / 11 / 2013$ \\
\hline & AP2M & Mobile & Stadspark & 45 & 7800 & $51^{\prime} 12^{\prime} 48^{\prime \prime} \mathrm{N}$ & $4^{\circ} 24^{\prime} 51^{\prime \prime} \mathrm{E}$ & $07 / 10 / 2013$ & $04 / 11 / 2013$ \\
\hline \multirow[t]{3}{*}{ Leicester } & LE1 & Fixed & Leicester University & 140 & 22500 & $52^{\circ} 37^{\prime} 12^{\prime \prime} \mathrm{N}$ & $1^{\circ} 07^{\prime} 38^{\prime \prime} \mathrm{E}$ & $25 / 10 / 2013$ & $31 / 03 / 2015$ \\
\hline & LE1M & Mobile & Leicester University & 140 & 22500 & $52^{\circ} 37^{\prime} 12^{\prime \prime} \mathrm{N}$ & $1^{\circ} 07^{\prime} 38^{\prime \prime} \mathrm{E}$ & $04 / 03 / 2014$ & $04 / 04 / 2014$ \\
\hline & LE2M & Mobile & Brookfield & 150 & 20500 & $52^{\circ} 37^{\prime} 15^{\prime \prime} \mathrm{N}$ & $1^{\circ} 06^{\prime} 32^{\prime \prime} \mathrm{E}$ & $05 / 04 / 2014$ & $29 / 05 / 2014$ \\
\hline \multirow[t]{2}{*}{ London } & LO1 & Fixed & Eltham & 60 & 16500 & $51^{\circ} 27^{\prime} 09^{\prime \prime} \mathrm{N}$ & $0^{\circ} 04^{\prime} 14^{\prime \prime} \mathrm{E}$ & $21 / 04 / 2014$ & $31 / 03 / 2015$ \\
\hline & LO1M & Mobile & Eltham & 60 & 16500 & $51^{\circ} 27^{\prime} 09^{\prime \prime} \mathrm{N}$ & $0^{\circ} 04^{\prime} 14^{\prime \prime} \mathrm{E}$ & $02 / 06 / 2014$ & $30 / 06 / 2014$ \\
\hline
\end{tabular}

${ }^{*}$ Mean traffic intensity (vehicles/day) at the nearest main street.

Table 2

Specifications of the employed UFP instrumentation.

\begin{tabular}{|c|c|c|c|c|c|c|c|c|}
\hline Name & Company/type & Lower size (nm) & Upper size (nm) & UFP size classes & Sample time (min) & Radioactive source & Condesation fluid & Deployed sites \\
\hline EPC & TSI 3783 & 7 & 1000 & 1 & 1 & - & Water & All \\
\hline UFPM & TSI 3031 & 20 & 500 & 6 & 10 & - & - & LE1, LO1 and Mobile \\
\hline SMPS & Grimm 5420 L-DMA & 10 & 1000 & 45 & 10 & ${ }^{85} \mathrm{Kr}(185 \mathrm{Mbq})$ & Butanol & AD1, AP1 and Mobile \\
\hline
\end{tabular}

campaign from December 2012 to January 2013 at an urban background location in Antwerp (Frijns et al., 2013). All EPCs and SMPSs were strongly correlated and differed by less than 10\% (except for the LE1 EPC; $13 \%$, probably due to the sampling setup which was changed following the colocation trial). The total number concentration, quantified by the EPC, was approximately $20 \%$ higher compared to the SMPS and 24\% higher compared to the UFPM. More details on the instrument comparisons can be found in the report by (Frijns et al., 2013). After installing the instruments at their monitoring locations, the mobile monitoring unit performed measurements adjacent to each monitoring site to evaluate the agreement of the instruments and reliability of the conducted measurements. Results of the mobile monitoring unit comparison can be found in the final Joaquin reporting (Joaquin, 2015).

\subsubsection{Meteorological data}

Meteorological data of ambient air temperature $\left({ }^{\circ} \mathrm{C}\right)$, relative humidity (\%), atmospheric pressure $(\mathrm{Pa})$, wind direction $\left(^{\circ}\right)$ and speed $\left(\mathrm{m} \mathrm{s}^{-1}\right)$ were obtained for each monitoring site. Meteorological parameters (e.g. wind) can be altered significantly at the local scale due to the urban canopy (e.g. building height, street orientation etc). Therefore, regional meteorological data were collected in addition to enable evaluation of larger-scale air mass transport processes. Regional meteorology was measured at a distance of $9 \mathrm{~km}$ from AD1 (Schiphol airport), $6 \mathrm{~km}$ from AP1 (Luchtbal monitoring station of the Flanders Environment Agency, VMM), $5 \mathrm{~km}$ from LE1 (Groby Road monitoring station) and $14 \mathrm{~km}$ from LO1 (Barking and Dagenham - Rush Green monitoring station).

\subsection{Data validation and treatment}

The raw 10 min-data were validated by screening for irregularities and removing data collected during instrument errors and maintenance periods. All validated data were subsequently 
aggregated to $30 \mathrm{~min}$ intervals. The retain threshold in further data averaging was $75 \%$ availability at the half-hourly level. For comparison purposes between the considered monitoring sites, sizeresolved UFP concentrations, obtained by the SMPS (45 size classes), were aggregated to the UFPM size classes: 10-20, 20-30, 30-50, 50-70, 70-100 and 100-200 nm.

Boxplots, single linear regression plots, coefficients of divergence (COD) and Spearman Rank $\left(r_{s}\right)$ correlations were applied to compare monitoring sites, time periods and pollutants. The COD provides information on the degree of uniformity between monitoring stations and is defined as

$C O D_{x y}=\sqrt{\frac{1}{n} \sum_{i=1}^{n}\left(\frac{c_{i x}-c_{i y}}{c_{i x}+c_{i y}}\right)^{2}}$

where $x$ and $y$ are the different monitoring stations, $c_{i x}$ is the ith observation of the pollutant concentration at monitoring location $x$, and $n$ is the number of observations. Small COD values imply similarities between the concentrations measured at various sites, while COD values approaching unity indicate vast differences between sites.

Potential effects of wind speed and direction were evaluated using pollution roses and polar plots. All statistical analyses were performed using the statistical software package $R$ ( $R$ Development Core Team, 2015), more specifically in the openair package (Carslaw and Ropkins, 2015, 2012).

\section{Results and discussion}

\subsection{Data exploration}

The 30 min air quality and meteorological data were collected for the entire sampling period, from April 2013, to March 2015. Taking into account the later start of the UFP measurements in Leicester and London (Table 1), data coverage at the 30 min was $96 \%$ for BC, $79 \%$ for total particle number concentrations (TNC) and 83\% for size-resolved particle number concentrations (PNC). This is comparable but generally lower than for the more commonly monitored pollutants $\mathrm{NO}_{2}$ (89\%), $\mathrm{PM}_{10}$ (94\%) and $\mathrm{PM}_{2.5}$ (81\%). The data range of $\mathrm{PM}, \mathrm{NO}_{2}, \mathrm{BC}$ and TNC was fairly comparable across the considered monitoring locations, except for Antwerp where higher overall concentrations of the typical traffic-related pollutants $\left(\mathrm{NO}_{\mathrm{x}}\right.$, $\mathrm{BC}$ and TNC) were observed (Table 3 ). This can be explained by its proximity $(30 \mathrm{~m})$ to a traffic-intensive access road into Antwerp (Plantin en Moretuslei). In February and October 2013, the mean traffic volume was 32000 vehicles on weekdays and 23500 vehicles in the weekend; or a time-weighted average of 29500 vehicles/day (VMM, 2014).

Looking at the range of the quantified total and size-resolved PNC (Table 3), comparable UFP variability was found at the monitoring sites, with the highest PNC observed in Antwerp. For all monitoring sites, the highest PNC were obtained in the smallest particle size class $(10-20 \mathrm{~nm})$, consecutively followed by the $30-50,20-30,50-70,70-100$ and $100-200 \mathrm{~nm}$ size classes. In Leicester and London, the $10-20 \mathrm{~nm}$ size class was not quantified due to the size range restrictions of the applied UFPM (see Table 2). Nevertheless, comparable behaviour of the $10-20 \mathrm{~nm}$ size class was observed from co-located SMPS measurements during the 2-4 week instrument comparison conducted by the co-located mobile monitoring unit (Joaquin, 2015).

\subsection{Temporal variation in TNC}

From the temporal variation plots of hourly-, daily- and monthly-averaged TNC, higher TNC are clearly observed in Antwerp, when compared to Amsterdam, Leicester and London (Fig. 2). A typical traffic-related diurnal variation was observed throughout the day, with distinct morning and evening peaks coinciding with traffic rush hours. During the weekends, the peaks were less pronounced and negligible during the morning rush hour, which seems to confirm road traffic as the main UFP attributor in urban environments, as reported earlier (Goel and Kumar, 2015; Kumar et al., 2014; Mishra et al., 2012; Querol et al., 2011; Reche et al., 2011). This was further confirmed when examining the temporal variation of BC (Appendix 1), which can be considered as a typical traffic-related pollutant. Similar diurnal variations, with distinct morning and evening peaks, and decreased concentrations during the weekend were identified. For all monitoring sites, the highest monthly-averaged TNC were obtained during winter months (September-March). This is likely due to meteorological conditions (e.g. temperature and mixing layer height) favouring higher atmospheric UFP concentrations, as reported before by Mishra et al. (2012), Pey et al. (2008) and Von Bismarck-Osten et al. (2013).

For the hourly-averaged diurnal UFP variation per particle size class (Fig. 3), comparable findings as for the TNC were observed, with a more or less constant ratio of the individual size classes, indicating a fairly stable UFP size distribution throughout time (also observed for the daily- and monthly-averaged PNC). However, temporal differences were observed for the 10-20 nm particle size class, which was only quantified in Amsterdam and Antwerp. For Amsterdam, a much higher relative contribution of the $10-20 \mathrm{~nm}$ class with respect to the other particle size classes was found compared to Antwerp (Fig. 3). Moreover, a constant contribution (>3000 particles $\mathrm{cm}^{-3}$ ) was observed throughout the day (7:00-20:00 h), while in Antwerp, the 10-20 nm sized particles followed the morning and evening rush hour peaks (Appendix 2). Also during the weekends, an average constant contribution of 10-20 nm sized particles was observed, while the PNC of all other size classes are observed to decrease considerably (Appendix 2). These data, therefore, suggest a non-traffic related input of mainly smaller-sized particles in Amsterdam. This UFP source seems to persist throughout the weekend, with the $10-20 \mathrm{~nm}$ size channel exhibiting a diurnal variation that is comparable to that observed during the working week. There was no clear decrease in the average PNC during the weekends, nor was there a seasonal influence.

\subsection{New particle formation events}

In Antwerp, the hourly-averaged $10-20 \mathrm{~nm}$ sized particles exhibit a distinct small midday-peak (Fig. 3), which was not observed for the other particle size classes (only to a limited extent in the $20-30 \mathrm{~nm}$ size class). This observation resembles at new photochemical particle formation (NPF) events in urban areas, as described in former studies (Brines et al., 2015; Kulmala and Kerminen, 2008; Pey et al., 2008; Querol et al., 2011; Reche et al., 2011; Wang et al., 2014).

Plotting the half-hourly averaged SMPS data ( 45 size bins) of the fixed urban locations, multiple days containing new particle formation (NPF) events could be identified in each city. While detailed size-resolved particle number concentrations could be collected from the SMPS measurements in Amsterdam (AD1; 730 days) and Antwerp (AP1; 730 days), only 6 UFP size classes were quantified by the UFPM in Leicester (LE1) and London (LO1). We, therefore, collected SMPS data from the co-located mobile unit to evaluate NPF events in Leicester (LE1M; 31 days) and London (LO1M; 28 days). Although the monitoring period was much shorter in Leicester and London, distinct nucleation events were observed at all monitoring locations, with $10-20 \mathrm{~nm}$ particle bursts starting around noon $(\mathrm{N})$ and lasting for approximately $2-4 \mathrm{~h}$ during which 
Table 3

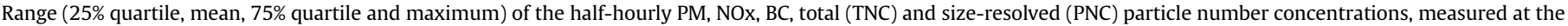
fixed monitoring sites in Amsterdam (AD1), Antwerp (AP1), Leicester (LE1) and London (LO1).

\begin{tabular}{|c|c|c|c|c|c|c|c|c|c|}
\hline & $\begin{array}{l}\text { Amsterdam } \\
\text { (AD1) }\end{array}$ & $\begin{array}{l}\text { Antwerp } \\
\text { (AP1) }\end{array}$ & $\begin{array}{l}\text { Leicester } \\
\text { (LE1) }\end{array}$ & $\begin{array}{l}\text { London } \\
\text { (LO1) }\end{array}$ & & $\begin{array}{l}\text { Amsterdam } \\
\text { (AD1) }\end{array}$ & $\begin{array}{l}\text { Antwerp } \\
\text { (AP1) }\end{array}$ & $\begin{array}{l}\text { Leicester } \\
\text { (LE1) }\end{array}$ & $\begin{array}{l}\text { London } \\
\text { (LO1) }\end{array}$ \\
\hline $\mathrm{PM}_{10}\left(\mu \mathrm{g} \mathrm{m}^{-3}\right)$ & & & & & PNC $10-20 \mathrm{~nm}$ & & & & \\
\hline $25 \%$ quartile & 12.24 & 15.00 & - & 11.30 & $25 \%$ quartile & 1125 & 1327 & - & - \\
\hline mean & 20.64 & 25.99 & - & 18.64 & mean & 2592 & 2468 & - & - \\
\hline $75 \%$ quartile & 25.21 & 32.50 & - & 22.50 & $75 \%$ quartile & 2956 & 3093 & - & - \\
\hline $\max$ & 227.50 & 176.25 & - & 122.50 & $\max$ & 56575 & 35412 & - & - \\
\hline $\begin{array}{c}\mathbf{P M}_{2.5}(\mu \mathrm{g} \\
\left.\mathbf{m}^{-3}\right)\end{array}$ & & & & & PNC 20-30 nn & & & & \\
\hline $25 \%$ quartile & 6.82 & 7.00 & 6.70 & 6.10 & $25 \%$ quartile & 805 & 974 & 755 & 475 \\
\hline mean & 14.24 & 16.17 & 13.47 & 13.00 & mean & 1552 & 1709 & 1541 & 1007 \\
\hline 75\% quartile & 17.66 & 20.47 & 16.70 & 15.90 & $75 \%$ quartile & 1773 & 2112 & 2001 & 1191 \\
\hline $\max$ & 225.30 & 145.00 & 181.00 & 90.40 & $\max$ & 39199 & 19634 & 13795 & 29072 \\
\hline $\mathrm{NO}_{2}\left(\mu \mathrm{g} \mathrm{m}^{-3}\right)$ & & & & & PNC 30-50 nn & & & & \\
\hline $25 \%$ quartile & 14.00 & 24.00 & 14.20 & 9.20 & $25 \%$ quartile & 1031 & 1278 & 891 & 811 \\
\hline mean & 25.49 & 41.37 & 27.13 & 20.63 & mean & 1773 & 2195 & 1774 & 1539 \\
\hline $75 \%$ quartile & 34.00 & 55.00 & 36.20 & 28.60 & $75 \%$ quartile & 2163 & 2704 & 2227 & 1946 \\
\hline $\max$ & 107.00 & 242.00 & 117.80 & 105.70 & $\max$ & 19756 & 26669 & 16641 & 22534 \\
\hline NO $\left(\mu \mathrm{g} \mathrm{m}^{-3}\right)$ & & & & & PNC 50-70 nm & & & & \\
\hline $25 \%$ quartile & 0.40 & 2.00 & 1.80 & 1.30 & $25 \%$ quartile & 537 & 717 & 594 & 426 \\
\hline mean & 4.89 & 17.56 & 11.07 & 6.60 & mean & 950 & 1267 & 1247 & 809 \\
\hline $75 \%$ quartile & 4.00 & 18.00 & 10.60 & 4.90 & $75 \%$ quartile & 1215 & 1598 & 1539 & 1042 \\
\hline $\max$ & 230.03 & 784.00 & 540.00 & 321.10 & $\max$ & 8907 & 15387 & 14614 & 8959 \\
\hline $\mathrm{BC}\left(\mu \mathrm{g} \mathrm{m}^{-3}\right)$ & & & & & PNC 70-100 n & & & & \\
\hline $25 \%$ quartile & 0.49 & 1.11 & 0.61 & 0.52 & $25 \%$ quartile & 362 & 553 & 504 & 400 \\
\hline mean & 1.01 & 2.36 & 1.40 & 1.22 & mean & 759 & 1063 & 1112 & 776 \\
\hline $75 \%$ quartile & 1.29 & 3.00 & 1.70 & 1.49 & $75 \%$ quartile & 1026 & 1382 & 1363 & 1012 \\
\hline $\max$ & 9.56 & 19.52 & 16.05 & 12.13 & $\max$ & 5546 & 5765 & 17444 & 10074 \\
\hline TNC $\left(\# \mathrm{~cm}^{-3}\right)$ & & & & & PNC 100-200 & & & & \\
\hline $25 \%$ quartile & 5889 & 8713 & 4760 & 5230 & $25 \%$ quartile & 363 & 604 & 447 & 319 \\
\hline mean & 9070 & 13481 & 8623 & 8353 & mean & 807 & 1182 & 1010 & 711 \\
\hline $75 \%$ quartile & 10952 & 16538 & 10916 & 10506 & $75 \%$ quartile & 1069 & 1531 & 1233 & 936 \\
\hline $\max$ & 76549 & 76170 & 63481 & 45155 & $\max$ & 20116 & 11903 & 19702 & 12707 \\
\hline
\end{tabular}

a modest growth in particle diameter can be observed of up to $40 \mathrm{~nm}(\mathrm{G})$, eventually suppressed by the condensation sink of the evening rush hour (Fig. 4). Road traffic emissions (T) can be observed, solely during evening rush hours on weekend days or holidays (AD1, AP1, LE and LO), while morning rush hours are also observed on working days (AD2 and AP2). While road traffic emissions ( $\mathrm{T}$ ) are clearly in the $30-50 \mathrm{~nm}$ size range, newly formed particles are much smaller, namely $(<) 10 \mathrm{~nm}$ which is the detection limit of the SMPS. The condensation sink effect of local traffic emissions, restraining growth of nucleation mode particles (Brines et al., 2015), can clearly be observed when comparing nucleation events between weekend/holidays and working days $\left(A D_{1}\right.$ vs $A D_{2}$ and $\mathrm{AP}_{1}$ vs $\mathrm{AP}_{2}$ in Fig. 4).

Following the classification procedure of Dal Maso et al. (2005), the considered monitoring days were classified as event or nonevent days (Table 4). Event days exhibit a distinct new particle (nucleation; 3-25 nm) mode which lasts for hours and shows signs of particle growth, while particles during non-event days display a bimodal size distribution with Aitken (25-100 nm) and accumulation (>100 nm) modes (Dal Maso et al., 2005). Days that did not fulfil either criteria, exhibiting sporadic occurrences of nucleation particles or growth in the Aitken mode, were classified as undefined. Finally, if missing data were obtained during the day, the entire day was classified as missing. Although consideration is needed when interpreting the short monitoring periods in Leicester and London, the calculated NPF frequencies confirm the existence of new particle formation events in the studied urban environments. The obtained frequencies of days containing NPF events are very similar between LE1M (13\%), AD1 (16\%) and AP1 (17\%), while more event days were observed in LO1M (36\%). In general, NPF events in the urban atmosphere are less favoured than in the rural atmosphere due to the high preexisting surface area for condensation of non-volatile materials needed for homogeneous nucleation (Dall'Osto et al., 2013). Previous studies in urban environments reported on similar NPF frequencies of $14-19 \%$ in Barcelona, Madrid and Brisbane (Brines et al., 2015), 13-20\% in Barcelona (Dall'Osto et al., 2013; Pey et al., 2008) and 23\% in Hong Kong (Wang et al., 2014), more intense nucleation events are observed in cleaner environments due to the lower pre-existing condensation sinks, with $24 \%$ in boreal forests (Dal Maso et al. 2005) and $>35 \%$ in the Himalayas (Venzac et al., 2008).

\subsection{Relationship with commonly-monitored pollutants}

To evaluate potential relationships between UFPs and more commonly monitored atmospheric pollutants, $30 \mathrm{~min}$ and dailyaveraged TNC was plotted against $\mathrm{PM}_{10}, \mathrm{PM}_{2.5}, \mathrm{NO}_{2}, \mathrm{NO}$ and $\mathrm{BC}$ concentrations per site. The TNC was linearly related with $\mathrm{BC}$ (Fig. 4), $\mathrm{NO}_{2}$ (not shown) and $\mathrm{NO}$ (not shown), which confirms vehicle engines as an important source of UFPs at the studied sites.

However, at the Amsterdam site, relationships between these typical traffic-related pollutants and TNC were significantly weakened. Therefore, traffic may not be the dominant UFP source at this particular monitoring location. The presence of the low emission zone (Panteliadis et al., 2014) and/or contributions from other UFP sources might explain this lack of correlation between trafficrelated pollutants and TNC in Amsterdam.

The relationships observed between the atmospheric pollutants seemed to exhibit a seasonal variation (not shown). For Antwerp, the strongest correlation obtained between BC and TNC was observed during the winter season $\left(\mathrm{R}^{2}=0.64\right)$. The relationship was weakest during the summer season (June, July, August), which may suggest a higher contribution of non-traffic emitted UFPs, e.g. originating from new particle formation. 

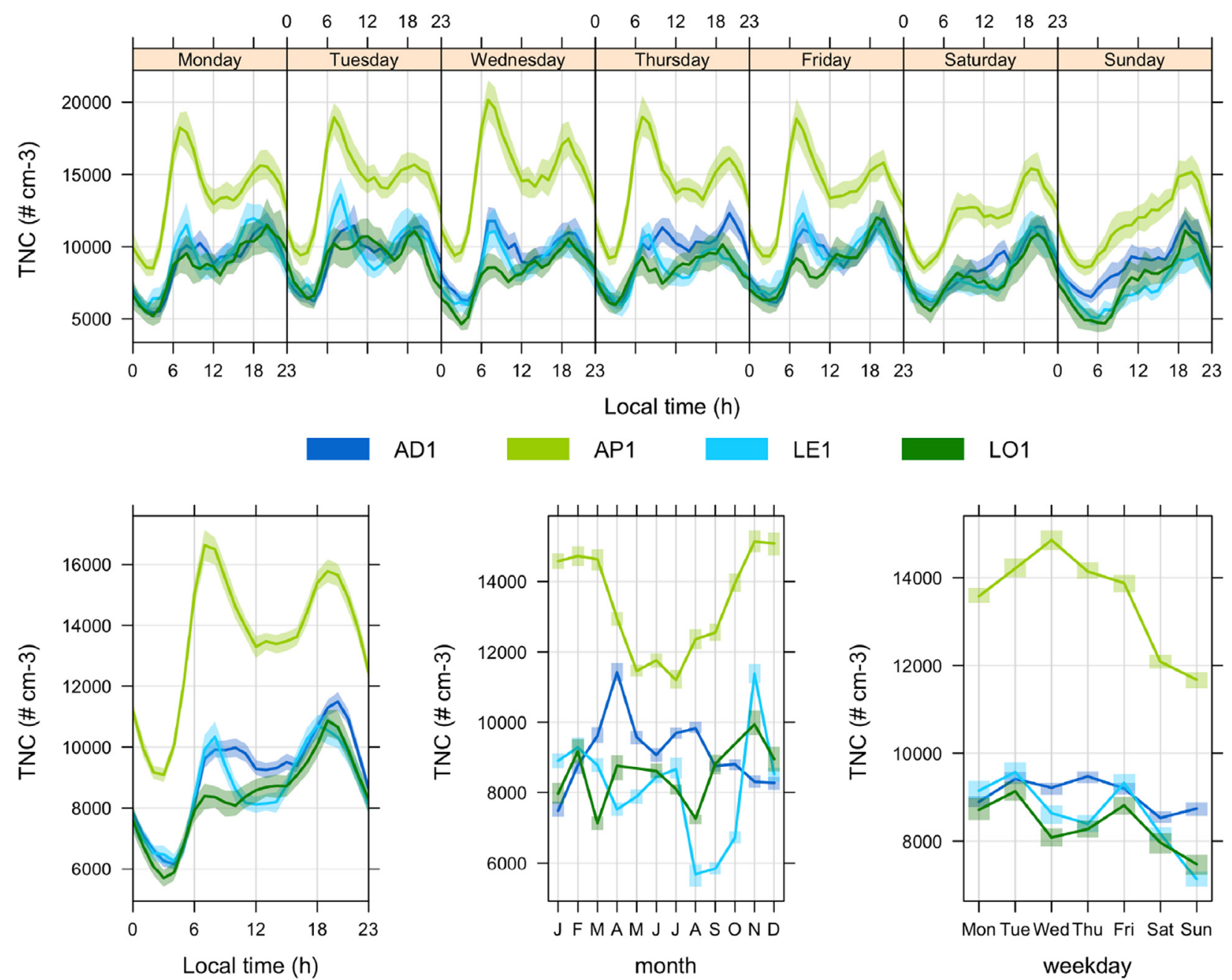

AD1

AP1

LE1

LO1

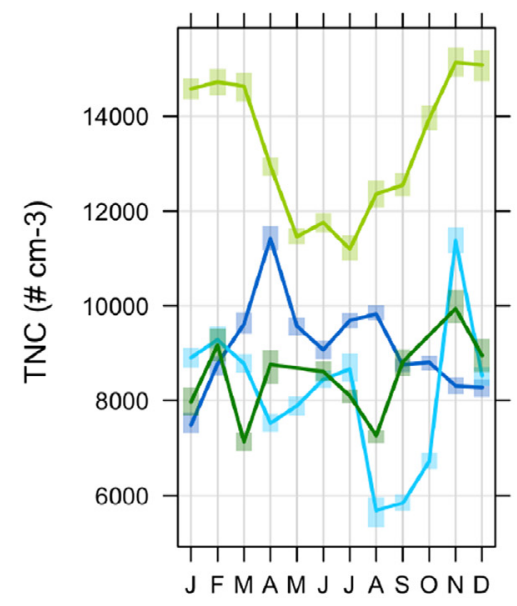

month

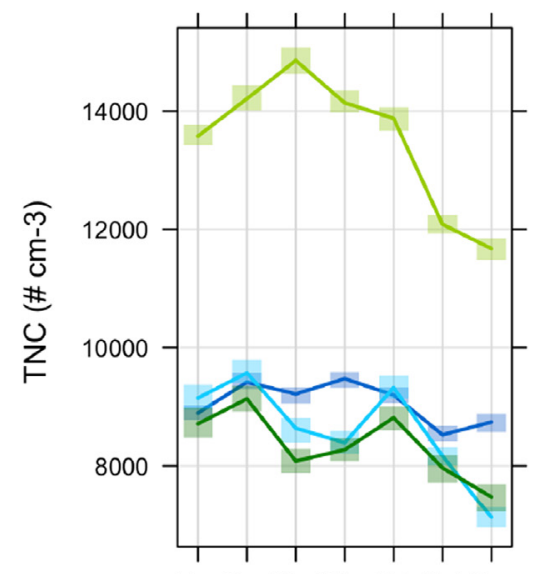

Mon TueWedThu Fri Sat Sun

weekday

mean and $95 \%$ confidence interval in mean

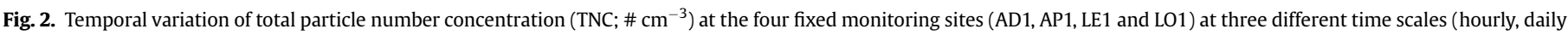

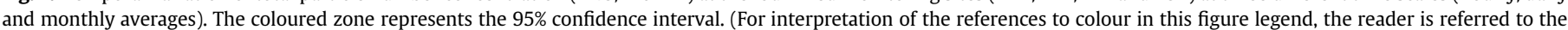
web version of this article.)
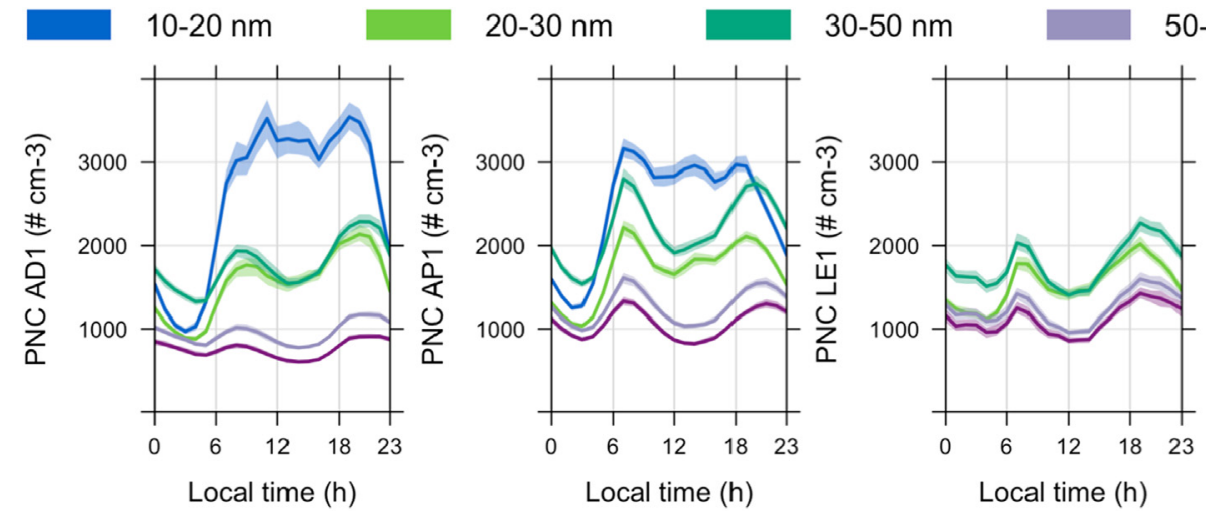

$50-70 \mathrm{~nm}$

$70-100 \mathrm{~nm}$

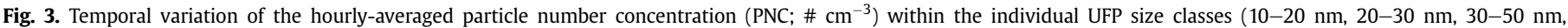
$50-70 \mathrm{~nm}, 70-100 \mathrm{~nm}$ ) at the four fixed monitoring sites (AD1, AP1, LE1 and LO1).

\subsection{Spatial variation}

\subsubsection{Inter-urban}

The average UFP size distributions within the aggregated particle size classes (Fig. 5) were generally similar between the considered monitoring locations. Nevertheless, Antwerp seemed to have a slightly higher contribution of 30-50 nm sized particles, while the $10-20 \mathrm{~nm}$ size range was proportionally higher in 

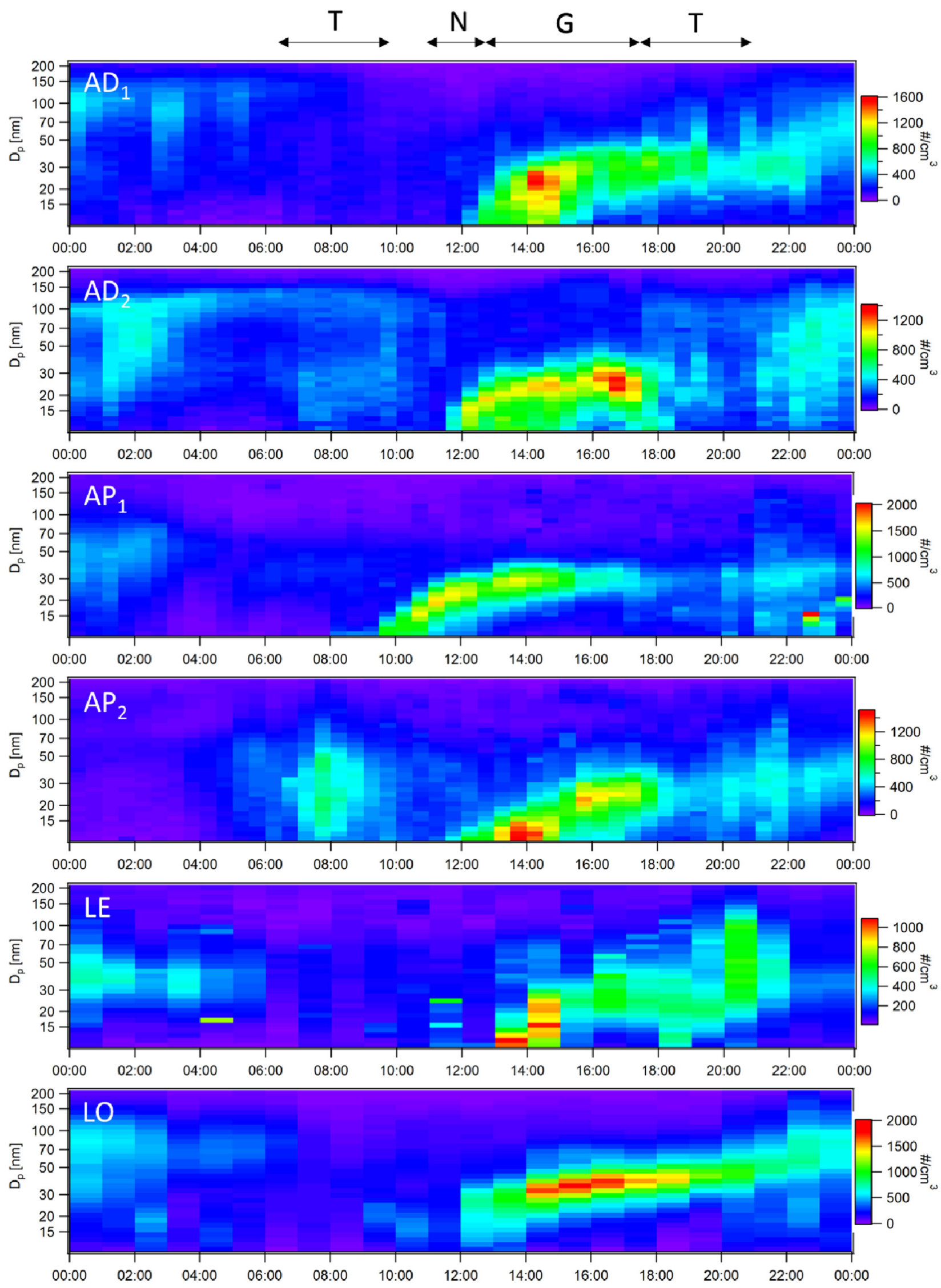

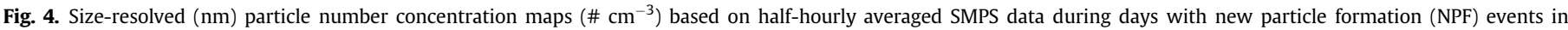

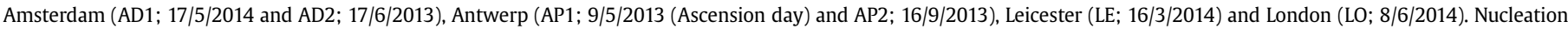
events are characterised by a nucleation burst phase $(N)$, followed by a particle growth phase $(G)$. 
Table 4

New particle formation events in the SMPS data obtained from Amsterdam (730 days), Antwerp (730 days), Leicester (31 days) and London (28 days) based on the classification scheme of Dal Maso et al. (2005).

\begin{tabular}{|c|c|c|c|c|c|c|c|c|}
\hline & \multicolumn{2}{|l|}{ AD1 } & \multicolumn{2}{|l|}{ AP1 } & \multicolumn{2}{|l|}{ LE1M } & \multicolumn{2}{|l|}{ L01M } \\
\hline & \# days & $\%$ & \# days & $\%$ & \# days & $\%$ & \# days & $\%$ \\
\hline Event & 118 & 16.16 & 121 & 16.58 & 4 & 12.90 & 10 & 35.71 \\
\hline Non-event & 56 & 7.67 & 104 & 14.25 & 5 & 16.13 & 0 & 0.00 \\
\hline Undefined & 330 & 45.21 & 355 & 48.63 & 20 & 64.52 & 9 & 32.14 \\
\hline Missing & 226 & 30.96 & 150 & 20.55 & 2 & 6.45 & 9 & 32.14 \\
\hline
\end{tabular}

Amsterdam. When normalized for size bin width $\left(\mathrm{dN}(\mathrm{dlog} D \mathrm{p})^{-1}\right)$, highest PNC were obtained near 30-50 nm, except for Amsterdam $(20 \mathrm{~nm})$. The TNC was significantly higher in Antwerp, compared to the other monitoring sites (Fig. 5). This can be explained by considering the proximity $(30 \mathrm{~m})$ of the monitoring site to a very busy access road into Antwerp (Plantin en Moretuslei). All other monitoring sites are located further away from road traffic (Fig. 1) and their nearest roads experience lower traffic volumes.

The spatial TNC variation was evaluated by calculating the coefficients of divergence (COD) and Spearman rank correlation coefficients $\left(r_{s}\right)$ between data pairs of the considered monitoring sites (Table 5). Most variation in TNC was observed between the sites in Antwerp and Leicester (COD $=0.37, r_{S}=0.30$ ), while the best agreement in TNC was found between Leicester and London $\left(\mathrm{COD}=0.28, \mathrm{r}_{\mathrm{s}}=0.50\right)$. Overall, correlations are fairly low $(\leq 0.5)$ indicating that TNC is not related at the regional level of NW Europe and that much of the variation in TNC is, as expected, owing to local factors.

The COD and correlation coefficients of the individual size classes (Appendix 3) indicate an increased association (smaller COD and larger correlation) was obtained with increasing particle size. As expected, larger particles tend to be more uniform, indicating the regional nature of these aerosols. Long-range transported aerosols comprise mostly of accumulation mode particles, with the major number peak mode around 100-200 nm (Vu et al., 2015).
Krudysz et al. (2009) previously found an inverse relationship between particle size and CODs for 13 different monitoring locations within $350 \mathrm{~m}-11 \mathrm{~km}$ of each other within the city of Los Angeles.

\subsubsection{Intra-urban}

To explore the spatial TNC variation within the investigated urban environments, a second urban background location (2 M) was sampled by means of the mobile monitoring unit in Amsterdam, Antwerp and Leicester (Table 1).

The hourly-averaged temporal variation plots (Fig. 6) show that the TNC concentrations at the fixed and mobile monitoring unit locations per city covary in time. In particular for Antwerp and Leicester, the covariance between the two sites seems good, while for Amsterdam some deviations between the sites was observed. The temporal UFP variation seems to consist of two levels. First, there is a (slowly changing) base level which behaves roughly similar in time and magnitude at both paired sites. In particular, this is the case in Antwerp and Leicester, while in Amsterdam there is a small difference of roughly $3000 \# / \mathrm{cm}^{3}$ between the sites. Looking at the individual particle size classes, it can be seen that this effect is predominantly observed in the $10-20 \mathrm{~nm}$ size class, which may be influenced by the different distances of the fixed and mobile sites, respectively, to Schiphol airport. In addition to this base level, part of the fast variation is observed at both sites per city. A clear example was seen in the time series for Antwerp: the peaks at the Stadspark location (AP2M) usually occur simultaneously at Borgerhout (AP1) but have a different magnitude. This was also found at the Leicester sites, and to a lesser extent, at the Amsterdam sites. This could be regarded as an overall urban contribution mostly originating from traffic emissions following a similar behaviour in time but differing in quantity depending on the distance to these emissions source. Apart from these contributions, certain local effects were noted affecting one site but not the other, as can be seen in Amsterdam, which is likely due to a differing influence of a nontraffic source.

In addition to the time series plots, coefficients of divergence
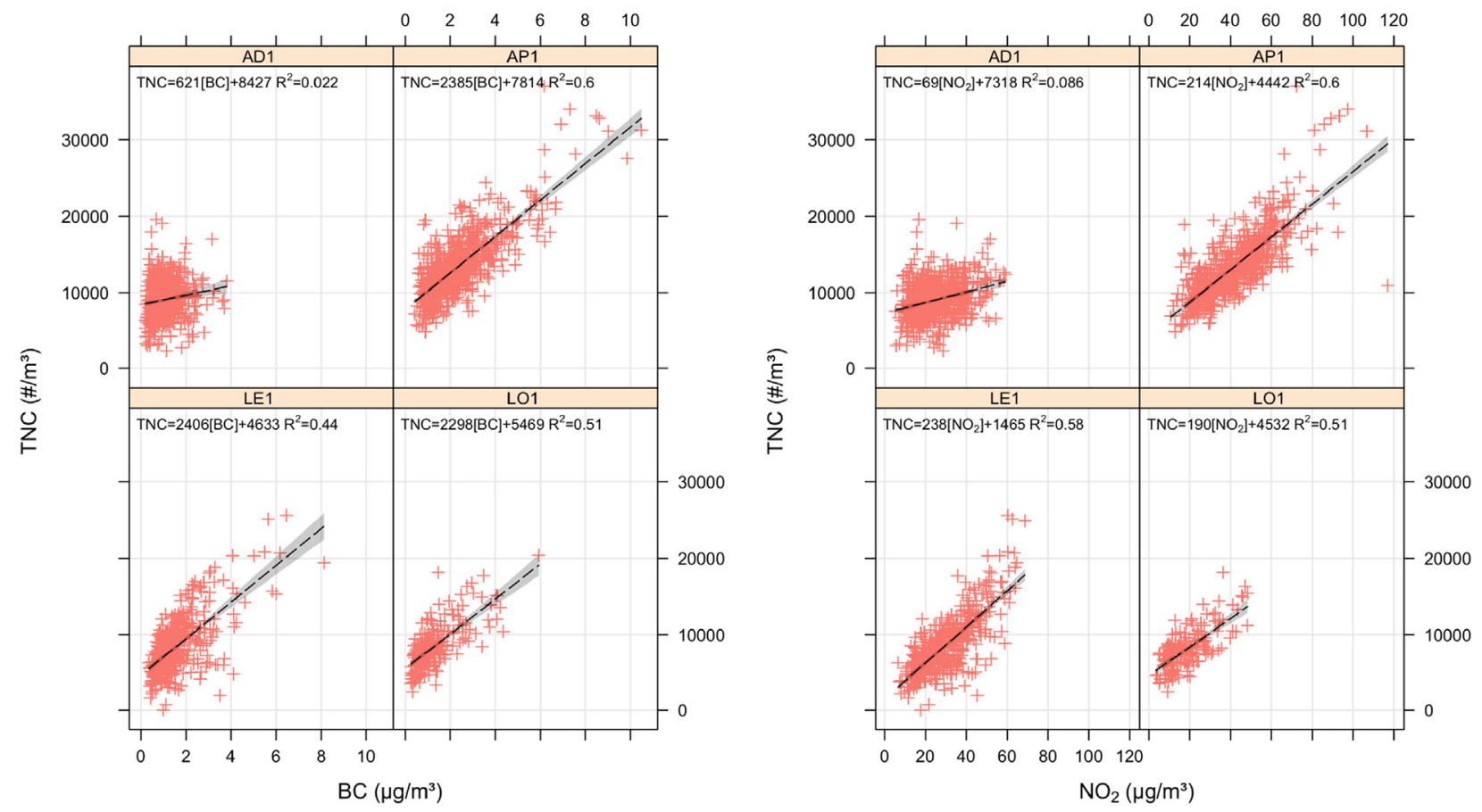

Fig. 5. Regression plots of daily-averaged $\mathrm{BC}\left(\right.$ left; $\mu \mathrm{g} / \mathrm{m}^{3}$ ) and $\mathrm{NO}_{2}$ (right; $\mu \mathrm{g} / \mathrm{m}^{3}$ ) versus $\mathrm{TNC}\left(\# / \mathrm{cm}^{3}\right)$ at the fixed monitoring sites $(\mathrm{AD} 1, \mathrm{AP} 1, \mathrm{LE} 1$ and $\mathrm{LO} 1)$. 
Table 5

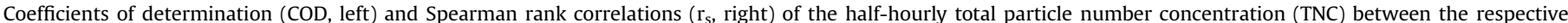
monitoring sites.

\begin{tabular}{|c|c|c|c|c|c|c|c|c|c|}
\hline \multicolumn{5}{|l|}{ COD TNC } & \multicolumn{5}{|c|}{ Spearman rank $\left(r_{s}\right)$ TNC } \\
\hline & Antwerp & Amsterdam & Leicester & London & & Antwerp & Amsterdam & Leicester & London \\
\hline Antwerp & 0.00 & 0.32 & 0.37 & 0.33 & Antwerp & 1 & 0.37 & 0.30 & 0.38 \\
\hline Amsterdam & 0.32 & 0.00 & 0.32 & 0.29 & Amsterdam & 0.37 & 1 & 0.31 & 0.28 \\
\hline Leicester & 0.37 & 0.32 & 0.00 & 0.28 & Leicester & 0.30 & 0.31 & 1 & 0.50 \\
\hline London & 0.33 & 0.29 & 0.28 & 0.00 & London & 0.38 & 0.28 & 0.50 & 1 \\
\hline
\end{tabular}
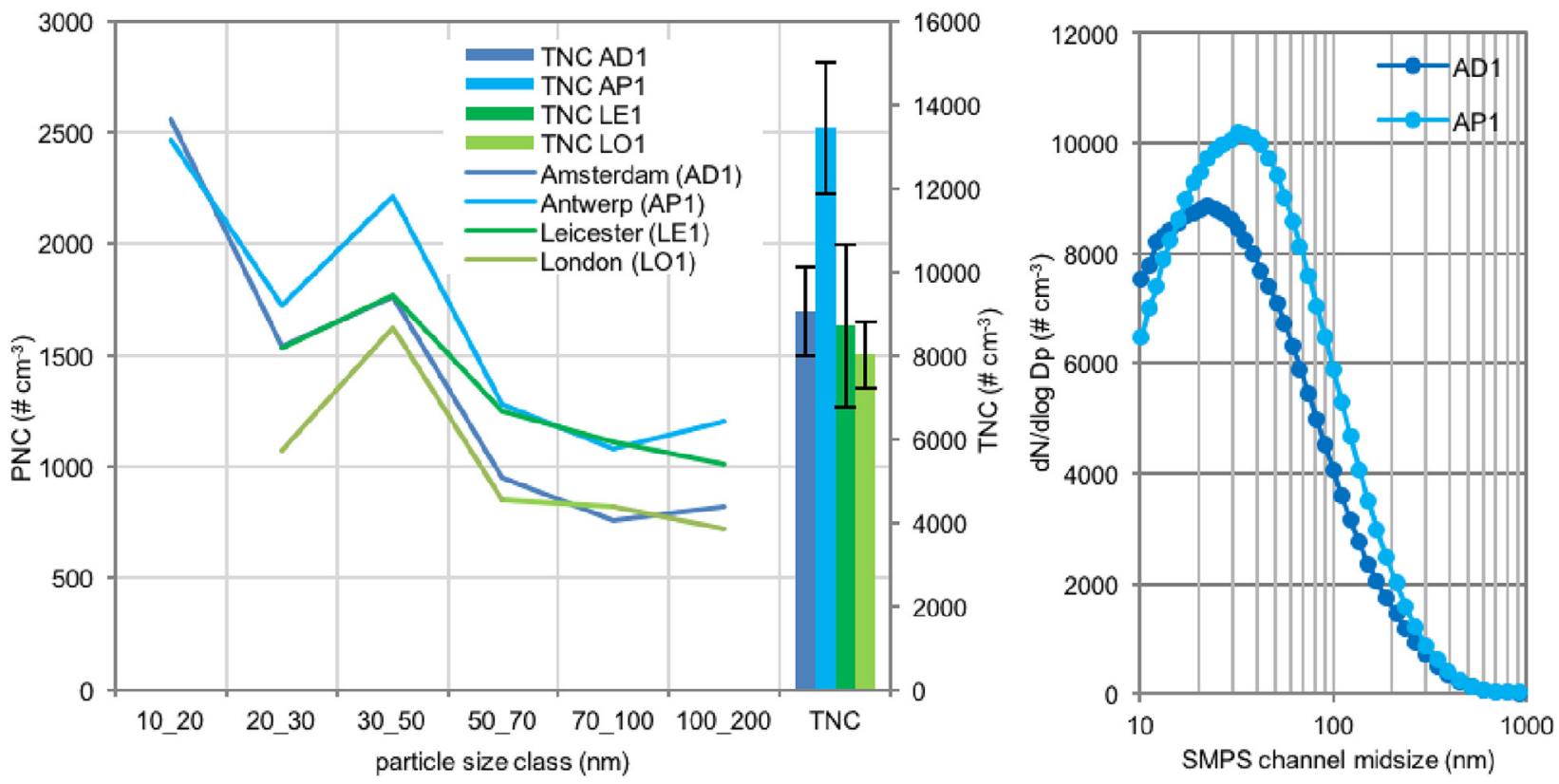

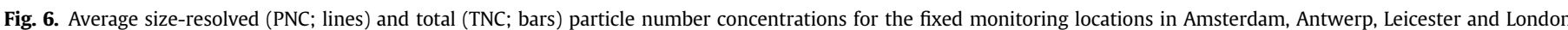
(left) and the full SMPS size distributions with 45 size classes $\left(\mathrm{dN} / \mathrm{d} \log \mathrm{D}_{\mathrm{p}}\right)$, obtained in Amsterdam and Antwerp (right).

(COD) and Spearman Rank correlations $\left(r_{s}\right)$ were calculated for the TNC between the fixed and mobile monitoring unit locations in the three cities. As already suggested by the time series plots, the highest association (lowest COD and highest $r_{s}$ ) was obtained in Antwerp $\left(\mathrm{COD}=0.16, \mathrm{r}_{\mathrm{s}}=0.85\right)$, followed by Leicester $(\mathrm{COD}=0.18$, $\left.\mathrm{r}_{\mathrm{s}}=0.77\right)$ and Amsterdam (COD $\left.=0.25, \mathrm{r}_{\mathrm{s}}=0.59\right)$.

Nevertheless, the average size distributions at the paired sites per city (Fig. 7) show large proportional differences in PNC, depending on the particle size class considered. On average, the largest intra-urban variation in TNC was observed in Antwerp (38\%), followed by Amsterdam (24\%) and Leicester (20\%). For Amsterdam, the 10-20 nm PNC was 48\% lower at the mobile unit location (AD2M, Nieuwendammerdijk), compared to the fixed monitoring station (AD1, Vondelpark). For Antwerp, the largest difference in size distributions was observed, with up to $49 \%$ lower particle numbers for AP2M in the $100-200 \mathrm{~nm}$ size range. This is not surprising, as the mobile unit location was within an urban park (Stadspark), while the fixed monitoring site was located $30 \mathrm{~m}$ from a busy access road (Table 1 ). In Leicester, the largest difference was observed in the 70-100 nm size range, with 30\% lower particle number concentrations at the mobile unit location (LE2M), compared to the fixed site (LE1).

Although the UFP number concentrations covaried in time at the monitored locations, considerable proportional differences in sizeresolved number concentrations were obtained between the individual intra-urban sites, influenced by their proximity to local UFP sources. This implies that the location of the UFP monitoring station is of primordial importance when evaluating citizen's exposure to UFP in urban environments. In epidemiological studies, UFP data from a single monitoring site are generally used as a measure of population exposure in a wider region. One reason for this is the lack of sufficient data at other sites, which may potentially result in exposure misclassification. While the spatial variation in particle mass concentration is known to be relatively low over an urban region, our results show that this is not the case for particle numbers.

\subsection{Influence of wind field on measured UFP concentrations}

All the monitoring sites in this study are classified as urban background stations. In order to assess the influence of local sources on the measured UFP concentrations, the potential effect of the experienced wind field on the total and size-resolved PNC was evaluated. In former studies, wind direction and speed have been shown to be the dominant influencing factors in the spatial variability of PNC (Keuken et al., 2015; Kozawa et al., 2012; Von Bismarck-Osten et al., 2013). From the wind roses shown in Fig. 8, it is clear that the main wind direction in Amsterdam, Antwerp and London is from the southwest.

Polar plots of TNC averaged according to wind direction and wind speed (Fig. 8, right panel) show clear site-dependent effects. While TNC was relatively independent of wind direction and wind speed in Leicester and London, Amsterdam and Antwerp show significant TNC variation depending on the experienced wind 

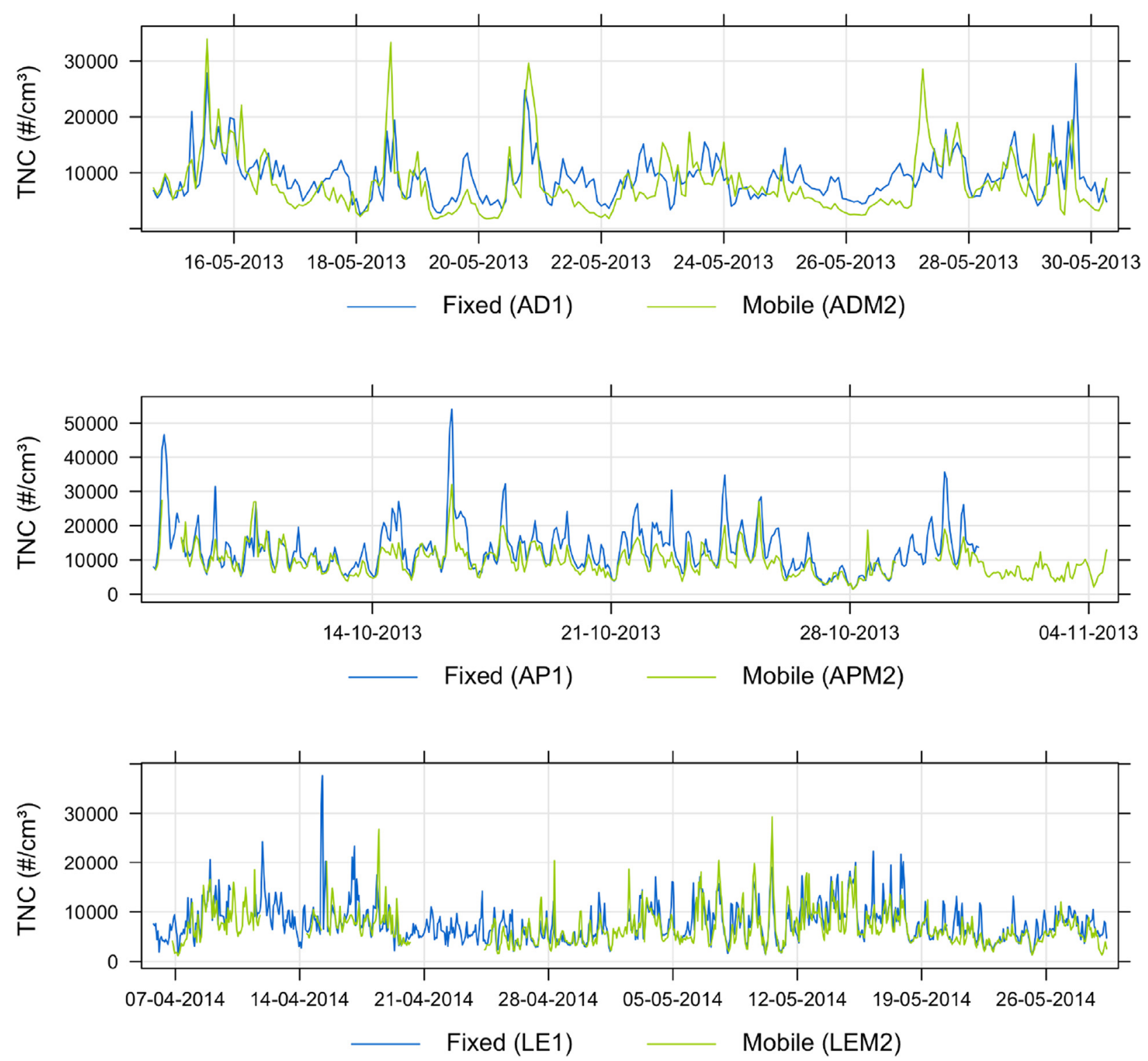

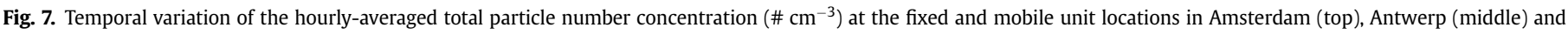
Leicester (bottom).

fields. Based on the polar plots, the location of contributing UFP sources can be derived. The polar plot for Antwerp indicated that the site is near a southern-located UFP source, namely the trafficintensive Plantin en Moretuslei. The highest UFP concentrations in Antwerp were observed under low wind speeds. At higher wind speeds, UFP emitted by the local traffic will be diluted, resulting in lower UFP concentrations. An additional UFP input can be observed when the wind is blowing from the NW, where streets at the other side of the monitoring site are located, as was also observed in (VMM, 2014). Looking at the individual size classes, the source effect of the Plantin en Moretuslei is most apparent for the 20-30 and 30-50 nm size classes (not shown). For the Amsterdam site, an average increase in TNC of $38 \%$ can be observed under strong SW winds. Looking at the individual size classes, the increase in TNC for SW winds was only observed for the $10-20$ and $20-30 \mathrm{~nm}$ size classes (not shown). This might be attributable to Schiphol airport emissions, in line with Keuken et al. (2015), who recently reported on a marked UFP increase in Amsterdam dominated by $10-20 \mathrm{~nm}$ sized particles during periods when the wind was blowing from the direction of Schiphol airport. The TNC increased by a factor of three at a monitoring station (Adamse Bos) located $7 \mathrm{~km}$ from Schiphol (Keuken et al., 2015). This study was later confirmed by Bezemer et al. (2015). A study near Los Angeles International airport reported on a comparable 4- to 5-fold increase in particle number concentrations downwind of the airport at 8-10 km (Hudda et al., 2014). Other studies near airports in Zurich (ACI EUROPE, 2012), Copenhagen (Ellermann et al., 2012; Møller et al., 2014), Stockholm (ACI EUROPE, 2012), Santa Monica (Hu et al., 2009) and Los Angeles (Westerdahl et al., 2008; Zhu et al., 2011) confirmed aviation as an important small-sized $(<40 \mathrm{~nm})$ UFP source, predominantly exhibited at the airport and downwind locations. The healthrelevance of these airport-related particles is however unclear due to the current lack of toxicological evidence.

Taking into account the location of the Amsterdam site (AD1) at approximately $8 \mathrm{~km}$ downwind of Schiphol Airport (Fig. 10), the non-traffic-related temporal variation of the $10-20 \mathrm{~nm}$ size range which persists throughout the weekends (see 3.3), and no clear relation between TNC and traffic-related pollutants (see 3.2), 

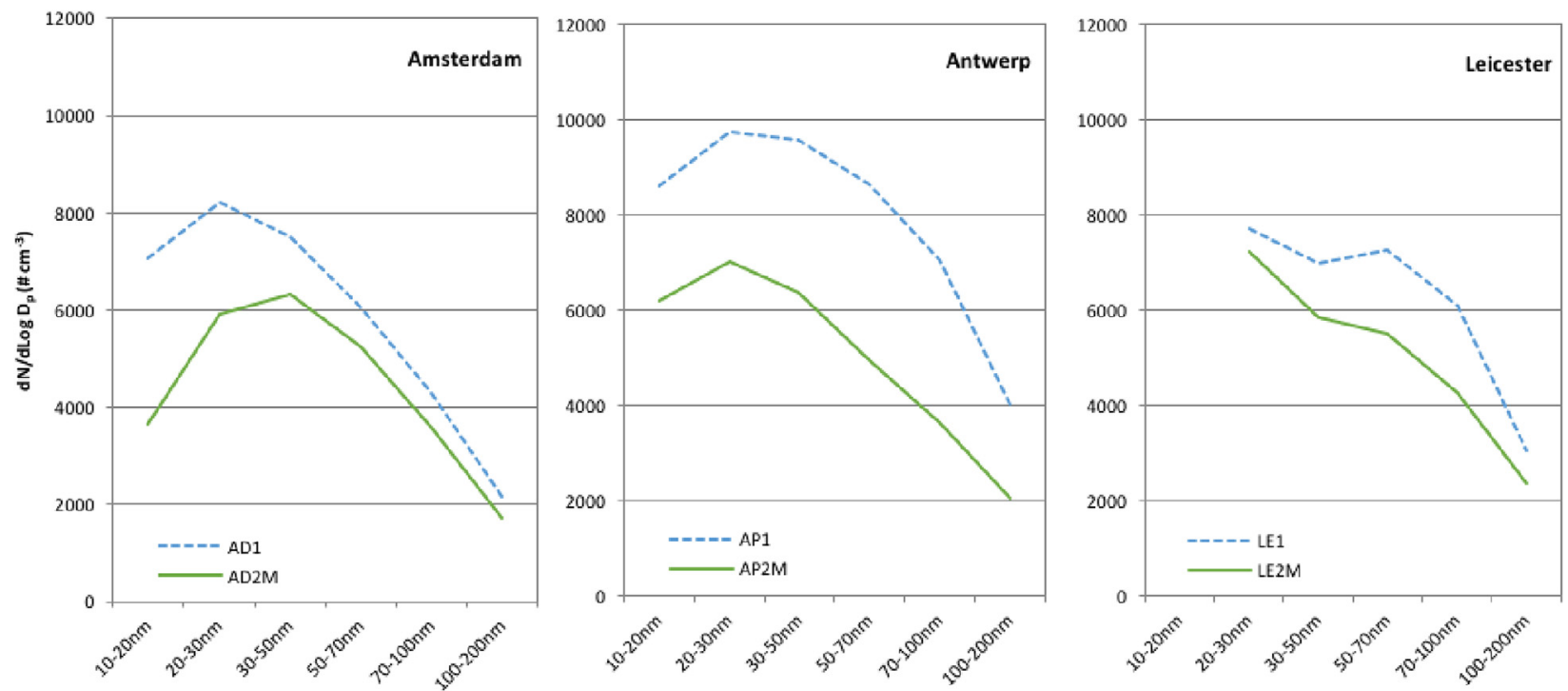

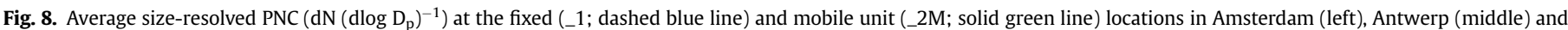
Leicester (right). (For interpretation of the references to colour in this figure legend, the reader is referred to the web version of this article.)

Schiphol seems to contribute to the urban UFP concentrations in Amsterdam. The TNC, measured at the AD1 site, was observed to increase by $34 \%$ when the wind was blowing from Schiphol $\left(205-245^{\circ}\right)$ compared to all other wind directions. As the city centre of Amsterdam is located downwind of Schiphol airport and south-westerly wind directions were experienced for $16 \%$ of the total monitoring time ( 5436 half-hourly values on a total of 34830 half-hourly values were between 205 and $245^{\circ}$ ), a significant attribution of Schiphol on citizens' exposure in Amsterdam can be expected. Taking into account the 34\% TNC increase and 16\% occurrence of $205-245^{\circ}$ wind directions, Schiphol airport determined $5.44 \%$ of TNC at the Amsterdam monitoring station near Vondelpark (city centre of Amsterdam). Plotting the PNC of the smallest size class (10-20 $\mathrm{nm}$ ) as a function of wind direction, this directional effect becomes much stronger as the $10-20 \mathrm{~nm}$ PNC is almost doubled (99\% increase) when wind is blowing from 205 to $245^{\circ}$ (Fig. 9). Although less clear due to the much shorter monitoring period ( 2 weeks) and the possible upwind influence of Amsterdam itself, higher $10-20 \mathrm{~nm}$ concentrations were obtained as well at the trailer location (AD2M) when the wind was blowing from the SW. Taking into account the $16 \%$ occurrence of $205-245^{\circ}$ wind directions, Schiphol airport accounted for $16 \%$ of the PNC of
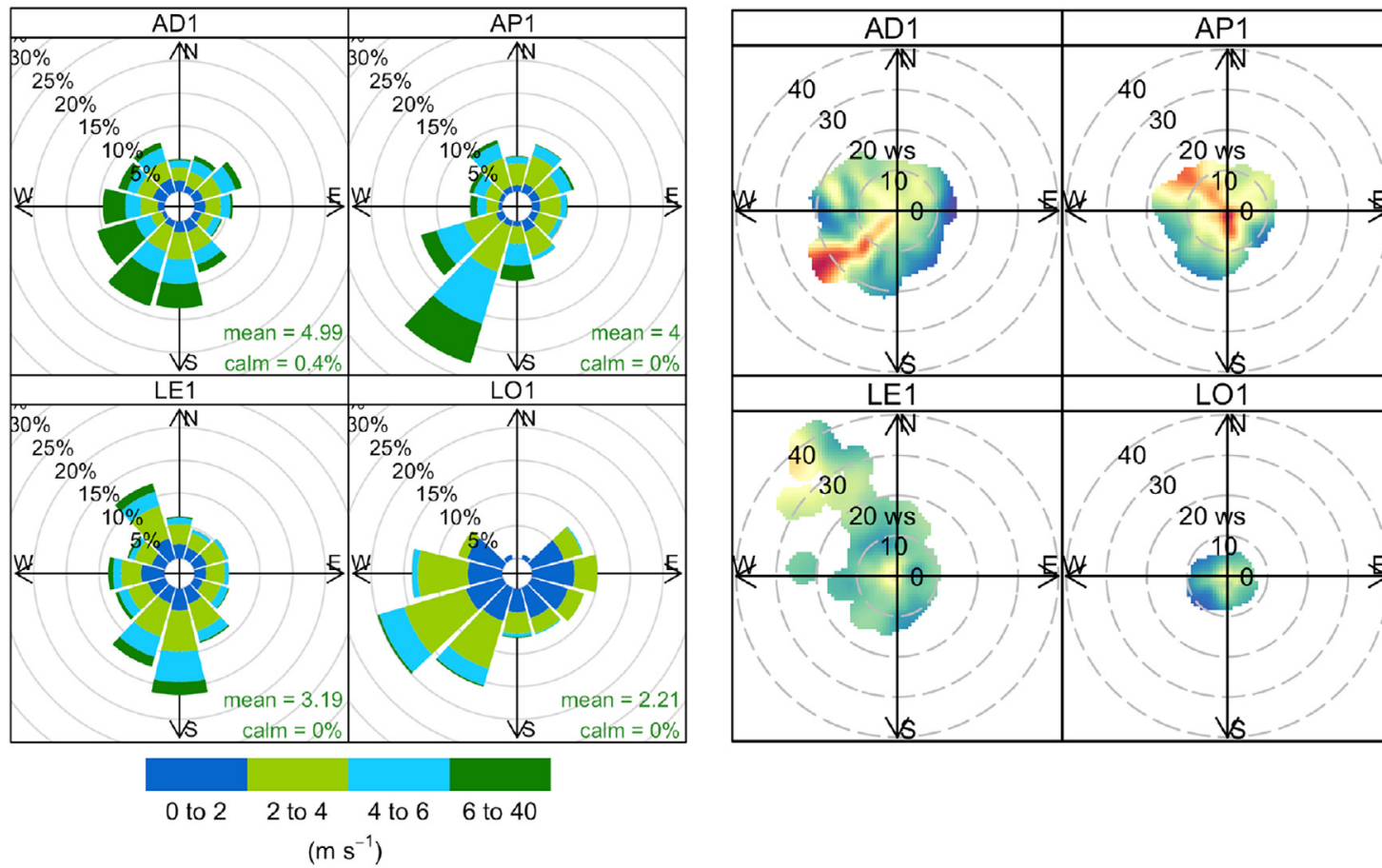

mean

20000

15000

10000

$-5000$

$$
\left(\mathrm{m} \mathrm{s}^{-1}\right)
$$

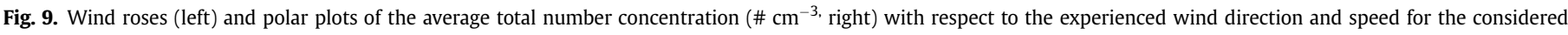
monitoring periods at the fixed monitoring sites in Amsterdam, Antwerp, Leicester and London. 


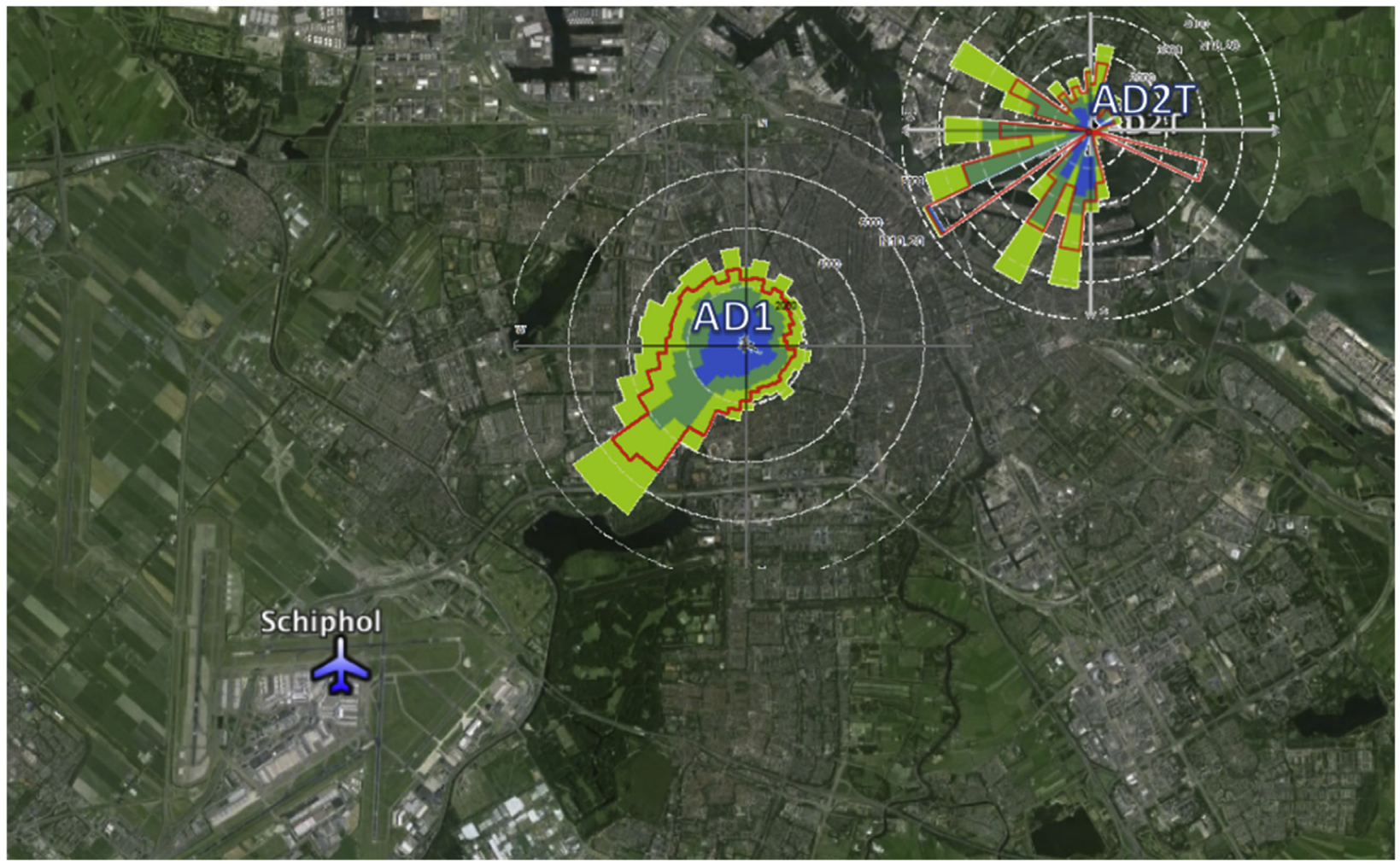

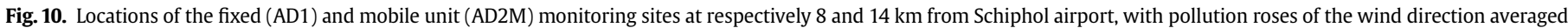
(red) 10-20 nm concentration per site. (For interpretation of the references to colour in this figure legend, the reader is referred to the web version of this article.)

10-20 nm particles at the AD1 monitoring site.

For Leicester, a slight increase in TNC was observed for periods in which wind was blowing from the west (NW-SW). Potential contributors might be East Midland airport and Radcliffe Soar power station, which are both located at about $27 \mathrm{~km} \mathrm{NW}$ of the considered monitoring site. These more distant source locations appear to be reflected in the observed contribution at the monitoring site under high $\left(>20 \mathrm{~m} \mathrm{~s}^{-1}\right)$ wind speeds. A north-south oriented main road (Welford Road) surrounded by residential areas is situated west of the Leicester site and a green area and Leicester University are situated east of the station. As the temporal variation shows a traffic-related diurnal variation, it can be assumed that the main road is contributing significantly to the measured PNC. The highest contribution in PNC during western wind conditions was observed for the $20-30 \mathrm{~nm}$ size class (not shown).

The site in London shows rather homogeneous particle number concentrations independent of the experienced wind fields. No clear effect of London Heathrow airport $( \pm 35 \mathrm{~km}$ in western direction) or London city airport ( $\pm 8 \mathrm{~km}$ north) was observed on the measured UFP concentrations. Based on the wind rose in Fig. 9 , London experienced negligible $(<1 \%)$ northern wind fields, excluding a potential influence of London city airport in our UFP data. Only during strong and eastern wind conditions, an increase in TNC was observed. This might be due to the Port of London, which is located at about $15 \mathrm{~km}$ in the eastern direction of the LO1 monitoring site. Previous studies already reported significant UFP contributions from shipping in coastal regions (González et al., 2011; Healy et al., 2009; Querol et al., 2011).

\section{Conclusion}

This study reports on a 1-2 year-long time series of total and size-resolved UFP number concentrations at four European urban background locations (Amsterdam, Antwerp, Leicester and London), supplemented with additional short-term mobile monitoring unit measurements (2-4 weeks) at an additional urban background location in Amsterdam, Antwerp and Leicester. The obtained time series provide important insights into the spatiotemporal variation of total and size-resolved UFPs in urban environments. While UFP sizing instruments represent feasible additions to air quality monitoring networks, best data coverage (comparable to traditional monitors) requires more maintenance and expertise than for traditional monitors. The co-located mobile monitoring unit provided a valuable addition to the fixed sites for harmonisation and validation purposes.

The fixed monitoring sites show comparable UFP size distributions with similar proportional contributions between the individual particle size classes $(100-200<70-100<50-70<20-30<30-50<10-20 \mathrm{~nm})$. Nevertheless, the size-resolved measurements enabled us to identify different contributing emission sources at different spatial scales. When comparing UFP size distributions between the various sites, better association was obtained between the larger UFP size classes $(>50 \mathrm{~nm})$. Larger particles, therefore, seem to be more uniform in space, which confirms the regional nature of these aerosols. Ambient UFP concentrations, in line with $\mathrm{BC}$ and $\mathrm{NO}_{2}$, showed clear traffic-related diurnal variation with distinct morning and evening rush hour peaks on week days, but only a clear evening peak during the weekends. Apart from the diurnal traffic-related variation, new particle formation events were observed in all cities for $13-36 \%$ of the days. Compared to the other sites, Antwerp experienced significantly higher TNC owing to its proximity to a busy road, confirming road traffic as an important UFP source in urban environments.

For Amsterdam, a clear increase in TNC due to increases in the 
10-20 and 20-30 nm PNC was observed during strong SW winds. In combination with the high and continuous $10-20 \mathrm{~nm}$ contribution throughout the week and the weaker relationships between UFP and $\mathrm{BC} / \mathrm{NO}_{\mathrm{x}}$, this suggests an influence of Schiphol airport on UFPs measured at a distance of $8 \mathrm{~km}$ in the city centre of Amsterdam. Taking into account the frequency of southwestly wind fields, and the proportional increase of total and $10-20 \mathrm{~nm}$ sized particles, Schiphol airport was estimated to potentially contribute up to $5 \%$ of TNC and $16 \%$ of $10-20 \mathrm{~nm}$ particles measured at the Amsterdam site.

The spatial variation of UFPs inside the respective cities was evaluated using simultaneous mobile monitoring unit measurements at additional urban background locations. Although covarying UFP concentrations were observed $\left(r_{s}=0.59\right.$ to 0.85$)$, the absolute difference in terms of particle numbers have been shown to be significant (up to $38 \%$ and $49 \%$ for total- and size-resolved particle numbers, respectively). As all monitoring sites are classified as "urban background" locations, the observed differences will likely even increase between more contrasting locations. This implies that the location of the UFP monitoring site is of primordial importance when evaluating citizen's exposure to UFPs in urban environments. Compared to the total number concentration, sizeresolved measurements have been shown to offer far more information on the type, origin and transformation processes of atmospheric aerosols. Moreover, by combining both total and sizeresolved UFP instruments, instrument anomalies can be detected more easily.

\section{Acknowledgements}

This research was carried out in the framework of the Joint Air Quality Initiative (Joaquin) project, supported by the EU INTERREG IVB NWE Programme. The corresponding author acknowledges the Research Foundation Flanders (FWO) for his postdoctoral fellowship.

\section{Appendix A. Supplementary data}

Supplementary data related to this article can be found at http:// dx.doi.org/10.1016/j.atmosenv.2016.04.010.

\section{References}

ACI EUROPE, 2012. Ultrafine Particles at Airports: Discussion and Assessment of Ultrafine Particles (UFP) in Aviation and at Airports in 2012.

Bezemer, A., Wesseling, J., Cassee, F., Fischer, P., Fokkens, P., Houthuijs, D., Jimmink, B., de Leeuw, F., Kos, G., Weijers, E., Keuken, M., Erbrink, H., 2015. Further Exploratory Study of Ultrafine Particulate Material Around Schiphol. RIVM.

Brines, M., Dall'Osto, M., Beddows, D.C.S., Harrison, R.M., Gómez-Moreno, F., Núñez, L., Artíñano, B., Costabile, F., Gobbi, G.P., Salimi, F., Morawska, L., Sioutas, C., Querol, X., 2015. Traffic and nucleation events as main sources of ultrafine particles in high-insolation developed world cities. Atmos. Chem. Phys. 15, 5929-5945. http://dx.doi.org/10.5194/acp-15-5929-2015.

Carslaw, D.C., Ropkins, K., 2012. Openair - An R package for air quality data analysis. Environ. Model. Softw. 27-28, 52-61. http://dx.doi.org/10.1016/ j.envsoft.2011.09.008.

Carslaw, D.C., Ropkins, K., 2015. Openair: Open-source Tools for the Analysis of Air Pollution Data. Natural Environment Research Council, London.

Dal Maso, M., Kulmala, M., Riipinen, I., Wagner, R., Hussein, T., Aalto, P.P., Lehtinen, K.E.J., 2005. Formation and Growth of Fresh Atmospheric Aerosols: Eight Years of Aerosol Size Distribution Data from SMEAR II. Hyytiälä, Finland.

Dall'Osto, M., Querol, X., Alastuey, A., O'Dowd, C., Harrison, R.M., Wenger, J., GómezMoreno, F.J., 2013. On the spatial distribution and evolution of ultrafine particles in Barcelona. Atmos. Chem. Phys. 13, 741-759. http://dx.doi.org/10.5194/ acp-13-741-2013.

Donaldson, K., Stone, V., Clouter, A., Renwick, L., MacNee, W., 2001. Ultrafine particles. Occup. Environ. Med. 58, 211-216.

Ellermann, T., Massling, A., Løfstrøm, P., Winther, M., Nøjgaard, J.K., Ketzel, M., 2012. Assessment of the Air Quality at the Apron of Copenhagen Airport Kastrup in Relation to the Occupational Environment. Aarhus University, DCE - Danish
Centre for Environment and Energy, p. 51. Technical report from DCE - Danish Centre for Environment and Energy No. 15. http://www2.dmu.dk/Pub/TR15.pdf.

Frijns, E., Van Jo, L., Aerts, W., Brabers, R., Berghmans, P., 2013. UFP Instrument Comparison at an Urban Background Location in Antwerp.

Goel, A., Kumar, P., 2015. Characterisation of nanoparticle emissions and exposure at traffic intersections through fast-response mobile and sequential measurements. Atmos. Environ. 107, 374-390. http://dx.doi.org/10.1016/ j.atmosenv.2015.02.002.

González, Y., Rodríguez, S., Guerra García, J.C., Trujillo, J.L., García, R., 2011. Ultrafine particles pollution in urban coastal air due to ship emissions. Atmos. Environ. 45, 4907-4914. http://dx.doi.org/10.1016/j.atmosenv.2011.06.002.

Harrison, R.M., Shi, J.P., Xi, S., Khan, A., Mark, D., Kinnersley, R., Yin, J., 2000. Measurement of number, mass and size distribution of particles in the atmosphere. Philosophical Trans. R. Soc. A Math. Phys. Eng. Sci. 358, 2567-2580. http:// dx.doi.org/10.1098/rsta.2000.0669.

Healy, R.M., O'Connor, I.P., Hellebust, S., Allanic, A., Sodeau, J.R., Wenger, J.C., 2009 Characterisation of single particles from in-port ship emissions. Atmos. Environ. 43, 6408-6414. http://dx.doi.org/10.1016/j.atmosenv.2009.07.039.

Hu, S., Fruin, S., Kozawa, K., Mara, S., Winer, A.M., Paulson, S.E., 2009. Aircraft emission impacts in a neighborhood adjacent to a general aviation airport in southern California. Environ. Sci. Technol. 43, 8039-8045. http://dx.doi.org/ 10.1021/es900975f.

Hudda, N., Gould, T., Hartin, K., Larson, T.V., Fruin, S.A., 2014. Emissions from an international airport increase particle number concentrations 4 -fold at $10 \mathrm{~km}$ downwind. Environ. Sci. Technol. 48, 6628-6635. http://dx.doi.org/10.1021/ es5001566.

Joaquin, 2015. Monitoring of Ultrafine Particles and Black Carbon. Joint Air Quality Initiative, Work Package 1 Action 1 and 3.

Kelly, F.J., Fussell, J.C., 2012. Size, source and chemical composition as determinants of toxicity attributable to ambient particulate matter. Atmos. Environ. 60, 504-526. http://dx.doi.org/10.1016/j.atmosenv.2012.06.039.

Keuken, M.P., Moerman, M., Zandveld, P., Henzing, J.S., Hoek, G., 2015. Total and size-resolved particle number and black carbon concentrations in urban areas near Schiphol airport (the Netherlands). Atmos. Environ. 104, 132-142. http:/ dx.doi.org/10.1016/j.atmosenv.2015.01.015.

Kozawa, K.H., Winer, A.M., Fruin, S.A., 2012. Ultrafine particle size distributions near freeways: effects of differing wind directions on exposure. Atmos. Environ. 63, 250-260. http://dx.doi.org/10.1016/j.atmosenv.2012.09.045.

Krudysz, M., Moore, K., Geller, M., Sioutas, C., Froines, J., 2009. Intra-community spatial variability of particulate matter size distributions in Southern California/ Los Angeles. Atmos. Chem. Phys. 9, 1061-1075. http://dx.doi.org/10.5194/acp-91061-2009.

Kulmala, M., Kerminen, V., 2008. On the formation and growth of atmospheric nanoparticles. Atmos. Res. 90, 132-150. http://dx.doi.org/10.1016/ j.atmosres.2008.01.005.

Kumar, P., Morawska, L., Birmili, W., Paasonen, P., Hu, M., Kulmala, M., Harrison, R.M., Norford, L., Britter, R., 2014. Ultrafine particles in cities. Environ. Int. 66, 1-10. http://dx.doi.org/10.1016/j.envint.2014.01.013.

Mishra, V.K., Kumar, P., Van Poppel, M., Bleux, N., Frijns, E., Reggente, M., Berghmans, P., Int Panis, L., Samson, R., 2012. Wintertime spatio-tempora variation of ultrafine particles in a Belgian city. Sci. Total Environ. 431, 307-313. http://dx.doi.org/10.1016/j.scitotenv.2012.05.054.

Møller, K.L., Thygesen, L.C., Schipperijn, J., Loft, S., Bonde, J.P., Mikkelsen, S., Brauer, C., 2014. Occupational exposure to ultrafine particles among airport employees-combining personal monitoring and global positioning system. PLoS ONE 9, e106671. http://dx.doi.org/10.1371/journal.pone.0106671.

Panteliadis, P., Strak, M., Hoek, G., Weijers, E., van der Zee, S., Dijkema, M., 2014. Implementation of a low emission zone and evaluation of effects on air quality by long-term monitoring. Atmos. Environ. 86, 113-119. http://dx.doi.org/ 10.1016/j.atmosenv.2013.12.035.

Petzold, A., Kramer, H., Schönlinner, M., 2002. Continuous measurement of atmospheric black carbon using a multi-angle absorption photometer. Environ. Sci. Pollut. Res. 4, 78-82.

Pey, J., Rodríguez, S., Querol, X., Alastuey, A., Moreno, T., Putaud, J.P., Van Dingenen, R., 2008. Variations of urban aerosols in the western Mediterranean. Atmos. Environ. 42, 9052-9062. http://dx.doi.org/10.1016/ j.atmosenv.2008.09.049.

Querol, X., Alastuey, A., Pey, J.P., Viana, M.V., Moreno, T., Minguillon, M., Amat, F. Pandolfi, M., Perez, N., Cusack, M., Reche, C., Dall'Osto, M., Ripoll, A. Karanasiou, A., 2011. Ultrafines in the Atmosphere.

R Development Core Team, 2015. R: a Language and Environment for Statistical Computing. R Foundation for statistical computing, Vienna, Austria.

Reche, C., Querol, X., Alastuey, A., Viana, M., Pey, J., Moreno, T., Rodríguez, S. González, Y., Fernández-Camacho, R., de la Rosa, J., Dall'Osto, M., Prévôt, A.S.H., Hueglin, C., Harrison, R.M., Quincey, P., 2011. New considerations for PM, Black Carbon and particle number concentration for air quality monitoring across different European cities. Atmos. Chem. Phys. 11, 6207-6227. http://dx.doi.org/ 10.5194/acp-11-6207-2011.

Venzac, H., Sellegri, K., Laj, P., Villani, P., Bonasoni, P., Marinoni, A., Cristofanelli, P., Calzolari, F., Fuzzi, S., Decesari, S., Facchini, M.C., Vuillermoz, E., Verza, G.P. 2008. High frequency new particle formation in the Himalayas. Proc. Natl. Acad. Sci. U. S. A. 105, 15666-15671. http://dx.doi.org/10.1073/pnas.0801355105.

Viana, M., Rivas, I., Reche, C., Fonseca, A.S., Pérez, N., Querol, X., Alastuey, A., ÁlvarezPedrerol, M., Sunyer, J., 2015. Field comparison of portable and stationary instruments for outdoor urban air exposure assessments. Atmos. Environ. 123 
220-228. http://dx.doi.org/10.1016/j.atmosenv.2015.10.076.

VMM, 2014. Intra-urban Variability of Ultrafine Particles in Antwerp (February and October 2013).

Von Bismarck-Osten, C., Birmili, W., Ketzel, M., Massling, A., Petäjä, T., Weber, S., 2013. Characterization of parameters influencing the spatio-temporal variability of urban particle number size distributions in four European cities. Atmos. Environ. 77, 415-429. http://dx.doi.org/10.1016/j.atmosenv.2013.05.029.

Vu, T.V., Delgado-Saborit, J.M., Harrison, R.M., 2015. Review: Particle number size distributions from seven major sources and implications for source apportionment studies. Atmos. Environ. 122, 114-132. http://dx.doi.org/10.1016/ j.atmosenv.2015.09.027.

Wang, D., Guo, H., Cheung, K., Gan, F., 2014. Observation of nucleation mode particle burst and new particle formation events at an urban site in Hong Kong. Atmos.
Environ. 99, 196-205. http://dx.doi.org/10.1016/j.atmosenv.2014.09.074

Westerdahl, D., Fruin, S., Fine, P., Sioutas, C., 2008. The Los Angeles International Airport as a source of ultrafine particles and other pollutants to nearby communities. Atmos. Environ. 42, 3143-3155. http://dx.doi.org/10.1016/ j.atmosenv.2007.09.006.

Zhu, Y., Fanning, E., Yu, R.C., Zhang, Q., Froines, J.R., 2011. Aircraft emissions and local air quality impacts from takeoff activities at a large International Airport. Atmos. Environ. 45, 6526-6533. http://dx.doi.org/10.1016/ j.atmosenv.2011.08.062

Zhu, Y., Hinds, W.C., Kim, S., Shen, S., Sioutas, C., 2002. Study of ultrafine particles near a major highway with heavy-duty diesel traffic. Atmos. Environ. 36, 4323-4335. http://dx.doi.org/10.1016/S1352-2310(02)00354-0. 


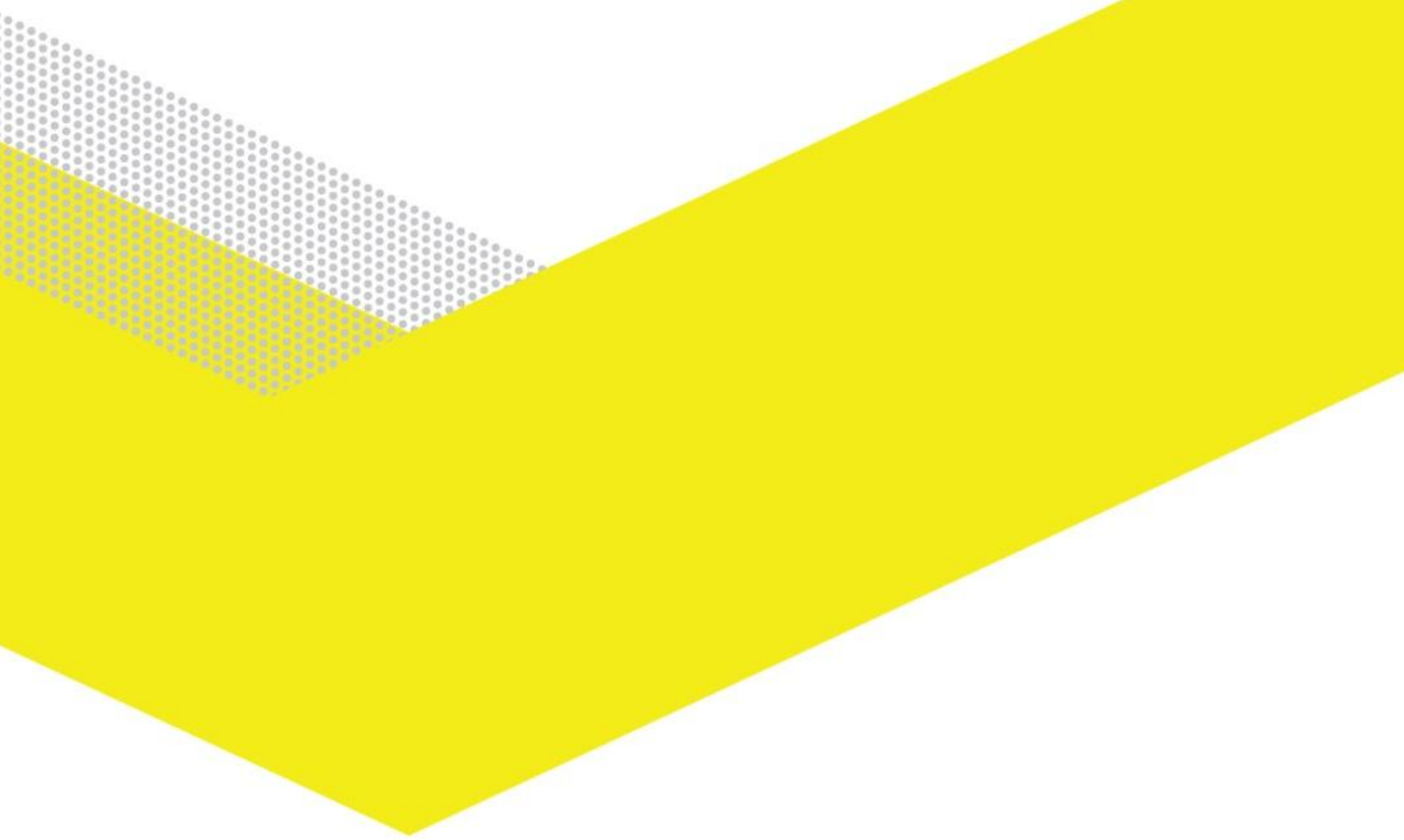

ECN

Westerduinweg 3

P.O. Box 1

1755 LE Petten

1755 ZG Petten

The Netherlands

The Netherlands

$T+31885154949$

$F+31885158338$

info@ecn.nl

www.ecn.nl 